\title{
Global patterns of sex- and age-specific variation in seabird bycatch
}

2

3

12
Dimas Gianuca a,b,^, Richard A. Phillips b, Stuart Townley a, Stephen C. Votier a

a Environment and Sustainability Institute, University of Exeter, Cornwall Campus, Penryn, TR10 9EF, UK

b British Antarctic Survey, Natural Environment Research Council, High Cross, Madingley Road, Cambridge, CB3 OET, UK

Authors email addresses:

Dimas Gianuca, dg286@exeter.ac.uk

Richard A. Phillips, raphil@bas.ac.uk

Stuart Townley, s.b.townley@exeter.ac.uk

Stephen C. Votier, s.c.votier@exeter.ac.uk

^Corresponding author.

E-mail address: dg286@exeter.ac.uk

Phone number: +44(0)7765 135603

Post address: Environment and Sustainability Institute, University of Exeter, Cornwall Campus, Penryn, TR10 9EF, UK 
Fisheries bycatch is a major threat to seabird populations, and understanding sex- and age-biases in bycatch rates is important for assessing population-level impacts. We analysed 44 studies to provide the first global assessment of seabird bycatch by sex and age, and used generalised models to investigate the effects of region and fishing method. Bycatch was highly biased by sex ( $65 \%$ of 123 samples) and age ( $92 \%$ of 114 samples), with the majority of samples skewed toward males and adults. Bycatch of adults and males was higher in subpolar regions, whereas there was a tendency for more immatures and females to be killed in subtropical waters. Fishing method influenced sex- and age-ratios only in subpolar regions. Sex- and age-biases are therefore common features of seabird bycatch in global fisheries that appear to be associated largely with differences in at-sea distributions. This unbalanced mortality influences the extent to which populations are impacted by fisheries, which is a key consideration for at-risk species. We recommend that researchers track individuals of different sex and age classes to improve knowledge of their distribution, relative overlap with vessels, and hence susceptibility to bycatch. This information should then be incorporated in ecological risk assessments of effects of fisheries on vulnerable species. Additionally, data on sex, age and provenance of bycaught birds should be collected by fisheries observers in order to identify regions and fleets where bycatch is more likely to result in population-level impacts, and to improve targeting of bycatch mitigation and monitoring of compliance.

Keywords: age ratio; incidental mortality; seabirds; fisheries management, sex ratio.

\section{Introduction}

Fisheries are one of the primary threats to marine biodiversity, impacting ecosystems from the open ocean to the coast, and from the poles to the tropics (Halpern et al., 2008; Jackson et al., 2001). Commercial fishing has resulted in severe and widespread ecosystem disruption primarily as a result of over-harvesting, habitat degradation and the mortality of non-target species, also called bycatch (Hall et al., 2000; Halpern et al., 2008; Jackson et al., 2001). Populations of large marine vertebrates, such as sea turtles, sharks, marine mammals, and seabirds, are particularly susceptible to bycatch because of a combination of their attraction to fishery bait and discards, and their naturally slow reproductive rates rendering them sensitive to even small increases in mortality (Hall et al., 2000; Lewison et al., 2004). The impacts are so extensive that the recent declines of many large marine vertebrates resulting from bycatch have been compared to the historical extirpations and extinctions of terrestrial megafauna by human hunting (Lewison et al., 2014, 2004).

Seabirds are particularly at risk from fisheries, as they are bycaught in a wide range of gear types (Croxall et al., 2012; Montevecchi, 2002; Phillips at al., 2016). For example, drift nets set by Japanese, Korean and Taiwanese vessels are estimated to have killed up to 40 million sooty (Ardenna grisea) and short-tailed (A. tenuirostris) shearwaters in the North Pacific between 1952 and 2001 (Uhlmann et al., 2005). Coastal gillnet fisheries are also a major source of mortality, with $>400,000$ seabirds killed annually, worldwide (Žydelis et al., 2013). Global longline fisheries are estimated to have killed at least 160,000, and potentially 320,000 seabirds annually, mainly albatrosses, petrels and shearwaters (Anderson et al., 2011). Trawl fisheries are also a threat, with about 9,300 birds, mostly albatrosses, estimated to be killed annually just in the waters off South Africa by wet fish trawls (Maree et al., 2014; Sullivan et al., 2006; Waugh et al., 2008). These levels of mortality have led to severe declines in many populations and are clearly unsustainable (Croxall et al., 1998; Cuthbert et al., 2005; Delord et al., 2008; Phillips at al., 2016; Piatt and Gould, 1994; Rolland et al., 2010; Žydelis et al., 2013, 2009). 
The impact of bycatch depends not only on the number of individuals killed, but also on the components of the population that are impacted (Bugoni et al., 2011; Lewison et al., 2012). For example, because seabird life histories are characterised by delayed maturation, high survival and low rates of reproduction, mortality of adults will have greater population-level impacts than mortality of immatures (Lewison et al., 2014). Moreover, because seabirds are monogamous, with obligate biparental care, sex-biased mortality in fisheries can reduce the effective population size (Mills and Ryan, 2005; Weimerskirch et al., 2005). Sex- and age-biases in seabird bycatch are reported in a number of fisheries (Awkerman et al., 2006; Gales et al., 1998; Ryan and Box-Hinzen, 1999; Stempniewicz, 1994), and there has been a review of adult sex-ratios (ASR) in bycatch of albatrosses and petrels (Bugoni et al., 2011). However, there has been no comprehensive review of sex- and age-biases in bycatch of seabirds in general, even though a better understanding of their nature and extent is required to determine the full impact of bycatch on populations and communities. Indeed, this has been identified as one of the highest priority research questions in the field of seabird ecology and conservation (Lewison et al., 2012; Phillips et al., 2016).

Accordingly, the aim of the current study is to provide the first global review of age- and sex-specific bycatch in seabirds. This will contribute towards a better understanding of the frequency and magnitude of these effects across taxa, regions and fishery gear-type, as well as the implications for management and conservation. We predict that larger and more dominant individuals, usually adult males, will have higher bycatch rates than adult females, or younger birds of either sex, because they are better able to compete for discards and baits while attending fishing boats (Awkerman et al., 2007b; Bregnballe and Frederiksen, 2006; Croxall and Prince, 1990; Montevecchi, 2002). However, bycatch rates will also be influenced by region. Many studies have shown that females and immatures tend to travel further from their breeding sites, or to lower latitudes, compared with males and adults (Hedd et al., 2014; Phillips et al., 2005, 2004). Therefore, because the majority of seabirds breed at high latitudes (Schreiber and Burger, 2002) we broadly predict that bycatch in subpolar (sub-Arctic and sub-Antarctic) areas will tend to be skewed towards males and adults, whereas in subtropical regions, bycatch will be biased towards females and immatures.

\section{Methods}

\subsection{Literature review}

We reviewed the literature for studies reporting sex and age composition of seabird bycatch in fisheries from around the world. We searched Thomson Reuters Web of Science and Google Scholar using the following search terms: Topic $=$ (seabird* OR albatross* OR

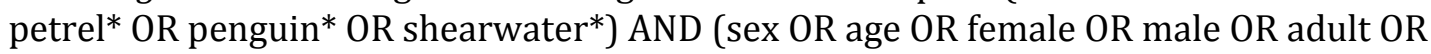
juvenile) AND (fishery* OR bycatch OR mortality) AND (bias); Timespan = All Years. To ensure the best possible coverage of the bycatch literature, we supplemented this with grey literature and contacted a number of experts directly to alert us to any missing references and to access unpublished studies. Only the studies reporting sex or age composition from samples of more than 10 individuals per species were included. We used the term 'immature' to refer to birds of any age below age of first breeding.

Authors utilized different methods for sexing including examination of gonads through necropsies (e.g. Petersen et al., 2010; Thompson et al., 2010a, b), molecular sexing (e.g. Burg, 2008; Jiménez et al., 2015b) and ring recoveries of known-sex individuals (e.g. Jiménez et al., 2015a). Birds were aged on the basis of plumage and bill morphology (e.g. Cardoso et al., 2011; Jiménez et al., 2015b; Neves and Olmos, 1997), or ring details for known-age individuals (Awkerman et al., 2006; Jiménez et al., 2015a; Österblom et al., 
2002). To aid interpretation, we classified each sample of seabird bycatch according to the magnitude of sex- and age-bias: highly biased ( $\geq 80 \%$ belonging to one sex or age class); biased (60\% - 79\%) and not biased (40\% - 59\%). The sampling unit for bycatch data refers to the information for each taxon caught in a particular gear type in each study. When possible, bycatch rates were separated by region and season (summer/winter).

To aid comparison across regions, the global oceans were initially divided into five major zones: sub-Antarctic, subtropical southern hemisphere, tropical, subtropical northern hemisphere and sub-Arctic. For the purpose of this study, sub-Arctic and subAntarctic zones also included the adjacent temperate waters. Thus, sub-Antarctic and subArctic regions mostly comprise waters between $60^{\circ}$ and $40^{\circ}$ of latitude (average sea surface temperature (SST) $0^{\circ}-18^{\circ} \mathrm{C}$ ), subtropical in both hemispheres between $40^{\circ}$ and $20^{\circ}$ of latitude (average SST $18^{\circ}-24^{\circ} \mathrm{C}$ ), and tropical between $20^{\circ} \mathrm{S}$ and $20^{\circ} \mathrm{N}$ (average SST $>25^{\circ} \mathrm{C}$ ). The exception was in the southern hemisphere, where cold water masses extend as far north as $30^{\circ} \mathrm{S}$ off the west coast of South America and to the south and south-west of Australia, which were included in sub-Antarctic waters (Figure 1). In modelling the regional effects on the sex- and age-ratios of seabird bycatch, sub-Antarctic and sub-Arctic areas were combined in "subpolar", and subtropical waters of both hemispheres combined in "subtropical".

We obtained data from a diverse range of fisheries, including pelagic and demersal longline, gillnet, trawl and pound net (shallow water nets attached to poles to create a funnel). Our sample, however, was dominated by two main gear types and variations therein: longline (pelagic and demersal) and gillnet. Longlines primarily kill surfacefeeding birds attracted to baited hooks near the surface, while gillnets mainly entrap pursuit divers and bottom feeders (Anderson et al., 2011; Žydelis et al., 2013).

\subsection{Data analysis}

We first compared the number of biased with non-biased (sex and age, respectively) bycatch samples for each fishery type, region and category using contingency tables. We specifically used chi-squared tests with Yates's correction for continuity where there was only one degree of freedom. We then tested for the effects of region (subpolar vs subtropical) and fishery type (longline [demersal and pelagic combined] vs gillnet) on the age and sex ratios of seabird bycatch using linear models followed by analyse of variance (ANOVA). We first ran liner mixed models using the lmer function of the lme 4 package in $\mathrm{R}$ (R Core Development Team, 2011; Zuur et al., 2009), including species as a random effect to account for inclusion in multiple datasets. Then, after verifying that the random-effect was not significant, it was dropped and linear models applied instead, using the function Im of the same package in R. The proportion of males or adults was used as the response variable for sex and age-bias respectively, using a Gaussian error distribution. Due to the unbalanced geographical distribution of bycatch samples by fishery type, we also tested the effect of the four major gear types (pelagic longline, demersal longline, gillnet and trawl) within the subpolar region. This was the only region with sufficient datasets. All models were weighted by the sample size, which, for the purpose of this analysis, was the number of birds of each taxon caught in a particular gear type in each study. We tested the effect of region and fisheries on sex and age proportions separately. Models were compared using second-order Akaike Information Criterion (AICc), where the best model is taken to be that with the lowest AICc value. AICc differences of $<2$ are not considered to be meaningfully different (Zuur et al., 2009).

\section{Results}


We found 44 studies, published between 1990 and 2016, that reported sex and age composition of seabird bycatch in fisheries, of which 35 (79\%) were in the southern hemisphere and $9(21 \%)$ in the northern hemisphere (Figure 1, Table 1). Data were available from four main types of fishery: 14 studies for pelagic longline (32\%), nine for demersal longline (20\%), nine for gillnet (20\%), two for trawl (5\%). Seven (16\%) studies reported data for more than one fishery, separated according to gear type. In addition, two studies combined data from intentional catch, and bycatch in gillnet and longline (5\%), and a single study (2\%) reported data from pound nets.

Availability of data from each fishery type was not equally distributed, geographically. For example, $82 \%(n=16)$ of the samples from demersal longline and $100 \%(\mathrm{n}=8)$ of those from trawl fisheries came from the sub-Antarctic region, $52 \%(\mathrm{n}=$ 27) of the pelagic longline samples from subtropical waters of the southern hemisphere, and $84 \%(\mathrm{n}=15)$ of the gillnet samples from sub-Arctic and adjacent subtropical waters combined (Figure 2).

The bycatch data with information on sex and age composition comprised 18,389 individuals of 41 seabird taxa, including 15 which are globally threatened: 16 albatrosses (Diomedeidae), nine petrels and shearwaters (Procellariidae), six sea ducks (Merginae), three penguins (Spheniscidae), two gulls (Laridae), two alcids (Alcidae), one grebe (Podicipedidae) and two cormorant/shags (Phalacrocoracidae) (Appendix A).

\subsection{Sex-specific bycatch}

Of 123 samples of sex ratios in seabird bycatch, 43 (35\%) were unbiased, 56 (46\%) were male-biased (including 20 that were highly biased,), and 24 (19\%) were female-biased (including five that were highly biased) (Figure 3-A, Appendix B). The number of sex-biased bycatch samples was significantly higher than the number of nonbiased $\left(\chi^{2}\right.$ Yates $\left.=10.537, P=0.001\right)$, and the number of samples skewed towards males was significantly higher than that skewed towards females $\left(\chi^{2}\right.$ Yates $\left.=12.013, P<0.001\right)$.

The geographical distribution of the highly sex-biased bycatch samples $(\geq 80 \%$ of one sex) is presented in Figure 4. There was a significant effect of the interaction between region and fishery type on the sex ratios of seabirds killed in fisheries, with the regional effect influencing the sex ratio of seabirds bycaught in longlines but not in gillnets (Figure 5 , Table 2). There was a higher proportion of males bycaught in fisheries in subpolar areas, whereas a trend towards female bycatch in subtropical waters $(F=38.464, P<$ 0.001 ) (Figure 6-A, Table 3). There was no significant difference in sex-ratios of seabird bycatch between gillnets and longlines (Figure 6-B, Table 3). However, when modelling the effect of the four major fishery gear-types within the subpolar region a significant effect was found $(F=10.556, P<0.01)$, with a higher mortality of males in trawl fisheries (Figure 7-A, Table 4).

\subsection{Age-specific bycatch}

Of 114 samples reporting age composition of seabird bycatch, nine (8\%) were unbiased, $78(68 \%)$ were skewed towards adults (62 were highly biased) and $27(24 \%)$ were biased towards immatures (12 were highly biased) (Figure 3-B, Appendix A). Age-biased bycatch was therefore widespread across global fisheries, accounting for $92 \%$ of reports $\left(\chi^{2}\right.$ yates $=$ $79.167, P<0.001$ ), with the frequency of adult-biased samples significantly larger than immature-biased $\left(\chi^{2}\right.$ Yates $\left.=23.810, P<0.001\right)$. 
The geographical distribution of the highly age-biased bycatch samples ( $\geq 80 \%$ of one age class) is presented in Figure 8. There was a significant effect of the interaction between region and fishery type on the age ratios of seabirds killed in fisheries, with the regional effect influencing the age ratio of seabirds bycaught in longlines but not in gillnets (Figure 5, Table 2). A higher proportion of adults was bycaught in subpolar regions whereas no difference was found in age-ratio of seabirds killed in subtropical areas $(F=$ 6.262, $P<0.05$ ) (Figure 6-C, Table 3 ). More adults than immatures were bycaught in longline, but there was no age bias for seabirds bycaught in gillnets $(F=13.578, P<0.001)$ (Figure 6-D, Table 3). Fishery type has a significant influence on the age ratio of seabirds bycaught in subpolar regions $(F=17.175, P<0.001)$ (Table 4$)$. Mortality of adults was significantly higher than of immatures in demersal longline and trawl fisheries than in other fishery types in these regions (Figure 7-B).

\section{Discussion}

Sex- and age-biases in seabird bycatch have been reported in a number of fisheries (Delord et al., 2005; Gales et al., 1998; Nel et al., 2002a; Phillips et al., 2010; Ryan and BoxHinzen, 1999), and there is growing interest in both the underlying mechanisms and the potential demographic consequences (Bugoni et al., 2011; Lewison et al., 2012). Here we provide the first global synthesis of both sex and age-specific variation in seabird bycatch rates by different fisheries and in diverse regions. Overall, our study shows substantial variation in the sex and age ratios of bycaught seabirds, and that unbalanced sex and age proportions are the most common pattern. Additionally, we demonstrate that sex- and age-biases vary by region and, to a lesser extent by fishery type. Globally, male-biased bycatch was significantly more frequent (47\%) than female-biased bycatch (18\%), and adult-biased (68\%) significantly more frequent than immature-biased (24\%). These results are consistent with our a priori prediction that the dominance of males and adults foraging behind fishing vessels will lead to higher bycatch. However, there are regional differences in the patterns of age- and sex-biased bycatch, as well as a disproportionately high number of studies from sub-polar waters (68\%), indicating that foraging despotism alone does not explain the observed patterns. Nevertheless, there is a paucity of this data in the northern hemisphere ( 9 studies) compared with the southern hemisphere (35 studies). Possible mechanisms contributing to unbalanced age and sex mortality, as well as its demographic effects, and implications for management and conservation, are discussed below.

\subsection{Sex-specific bycatch}

\subsubsection{Possible mechanisms contributing to sex-specific bycatch}

Although offspring sex-ratios in seabirds can vary with age, quality and timing of breeding (Blanchard et al., 2007; Velando et al., 2002; Weimerskirch et al., 2005,), there is little evidence for any consistent sex-biases at hatching or recruitment at the population level (Awkerman et al., 2007a; Bregtanole and Thibault, 1995; Donald, 2007; Weimerskirch et al., 2005). Therefore, the patterns observed here indicate that sexskewed bycatch is unlikely to be due to the underlying population sex-ratio. Hypotheses proposed to explain sex-related vulnerability to bycatch include sex-specific differences in at-sea distribution, and differential access to bait and discards related to sexual sizedimorphism and aggression (Barbraud et al., 2012; Bugoni et al., 2011; Nel et al., 2002a; Ryan and Box-Hinzen; 1999).

It has been suggested that the competitive advantage of males foraging behind fishing vessels explains male-biased bycatch events (Awkerman et al., 2006; Ryan and 
Box-Hinzen, 1999); however, there is little direct evidence to support this. Instead, in multi-species foraging aggregations, differences in body size between taxa are more important determinants of access to feeding opportunities than sex per se (Bugoni et al., 2011; Jimenez et al., 2012; Stauss et al., 2012; Votier et al., 2013). In contrast, sex-biased bycatch appears to be much better explained by sex-specific differences in distribution. For instance, in the southern hemisphere, our analysis showed a significantly higher frequency of male-biased bycatch in sub-Antarctic areas, but a trend towards the opposite pattern in subtropical waters; this is consistent with tracking and stable isotope results from a number of different sub-Antarctic seabird species during the breeding season, showing that females tend to forage farther from the colony and spend more time in subtropical waters compared with males (e.g. Hedd et al., 2014; Jiménez et al., 2015a; Nel et al. 2002b; Phillips et al., 2011, 2005, 2004; Thiers et al., 2014; Weimerskirch et al., 2014). In the northern hemisphere, where the bycatch data was more taxonomically heterogeneous and the sample size much smaller (15 species within 28 samples, 23\%), overall patterns of sex-biased bycatch are less clear. Nevertheless, differential distribution at sea has also been identified as a cause of male-biased mortality of common guillemot (Uria aalge) in coastal gillnets of Monterrey Bay (California) (Nevins et al., 2004), and for the male-skewed bycatch of both Laysan (Phoebastria immutabilis) and black-footed $(P$. nigripes) albatrosses off Alaska compared with the relatively balanced or female-biased sex-ratios of birds bycaught in Hawaiian waters (Beck et al., 2013). In the Baltic Sea, the sex-ratios of diving ducks bycaught in gillnets largely reflects the sex proportions observed in their wintering grounds (Stempniewicz, 1994), supporting the hypothesis of differential distribution as the main driver of observed bycatch bias. Therefore, the overall predominance of males in seabird bycatch that we found in our study probably reflects the higher proportion of samples obtained in subpolar areas (68\%), where the seabird mortality tend to be skewed toward males.

\subsubsection{Demographic effects of sex-specific bycatch}

The immediate effect of sex-biased bycatch could lead to skewed adult sex ratios and thus a reduction in effective population size (Donald, 2007; Millis and Ryan, 2005; Weimerskirch et al., 2005). For example, long-term demographic studies of wandering, black-browed (Thalassarche melanophris) and waved albatrosses (Phoebastria irrorata) all indicate sex-biases in survival that may be related to sex-specific bycatch (Arnold et al., 2006; Awkerman et al., 2006; Croxall et al., 1998; Weimerskirch and Jouventin, 1987). Nonetheless, it is very difficult to measure directly the demographic impact of sex-skewed mortality in fisheries because: (1) until now, there was a lack of systematic sex-specific seabird bycatch data across global fisheries; (2) there is often uncertainty about the provenance of bycaught birds, making it difficult to directly link events at sea with demographic monitoring on land; (3) there is a paucity of long-term demographic studies across multiple taxa and locations (Anderson et al., 2011; Lewison et al., 2012, 2004; Žydelis et al., 2013); and (4) there is uncertainty about other factors influencing sex differences in survival, such as relative predation risk, sex-specific costs of reproduction, variation in feeding strategies, or engagement in aggressive interactions (Donald, 2007; Weimerskirch et al., 2005). Mills and Ryan (2005) modelled the impact of sex-biased bycatch in wandering albatross and showed that even moderate increase in female mortality (2-4\% per year) reduces fecundity by $9-27 \%$ compared with unbiased mortality. This effect may explain the steep decline in the wandering albatross at South Georgia (Croxall et al., 1998; Croxall and Prince, 1990; Jiménez et al., 2015a; Poncet et al., 2006). Population-level effects of sex-biased bycatch have been observed in situations where there is reliable information on both bycatch rates and demographic traits. For example, in the waved albatross, which breeds almost entirely on Española Island (Galápagos Islands), there is a skew in the adult population towards females as a result of the strongly male-biased mortality (82\%) in artisanal fisheries off Peru and Ecuador 
(Awkerman et al., 2007a, 2006). In the wandering albatross at Possession Island (Crozet), the lower survival of females, attributed to higher mortality in pelagic longline fisheries, expected at South Georgia where females have a greater overlap with tuna fisheries in subtropical waters and consequently are bycaught more frequently than males (Jiménez et al., 2015a). Distorted sex ratios can also result in indirect effects on population dynamics, including unexpectedly high rates of extra-pair paternity in female-biased populations (Huyvaert et al., 2000), or reduced breeding success due to aggressive nest intrusions by unpaired males resulting in egg loss and infanticide in male-biased populations (Anderson et al., 2007; Taylor et al., 2001). These indirect effects, in tandem with the reduction of effective population size, can potentially increase the deleterious effects of bycatch on seabirds.

\subsection{Age-specific bycatch}

\subsubsection{Possible mechanisms contributing to age-specific bycatch}

Our review suggests that age-skewed seabird bycatch is common across global fisheries, with $68 \%$ of the bycatch samples skewed towards adults and $24 \%$ skewed towards immatures. The overall higher mortality of adults seems to agree with our initial prediction that dominant adults would outcompete immatures for foraging opportunities behind fishing vessels (Croxall and Prince, 1990). However, we must be cautious interpreting this result because the higher mortality of adults may largely reflect the typical age structure of seabird populations, which tend to be characterized by more adults than immatures (Nur and Sydeman, 1999). Detailed information on age-structure is lacking for most species and populations. Nevertheless, strong biases in both adult and immature bycatch suggest some extrinsic factors are in operation, and not that bycatch rates simply reflect the natural age ratios.

The degree to which different age classes interact with fisheries is not well understood (Lewison et al., 2012). However, some authors have proposed that juveniles may be more susceptible to bycatch because they favour scavenging over natural foods that may be more difficult to catch, or because of their naivety in avoiding fishing gear (Fayet et al., 2015; Lewison et al., 2012; Shealer, 2002,). Indeed, lack of experience while foraging around nets was considered to be the main reason for immature-biased mortality of pursuit-diving seabirds (Bregnballe and Frederiksen, 2006; Österblom et al., 2002). However, this is not a consistent pattern - in our study, $50 \%$ of the 12 samples of pursuitdiving seabirds of known age class drowned in nets were skewed towards adults, whereas $33 \%$ were skewed towards immatures. Naivety of young birds has also been suggested as the explanation for immature-skewed mortality in longlines, and potentially by trawls (Gales et al., 1998; Prince et al., 1994), but, again, this pattern was not supported by our data, which shows a large proportion of adults bycaught in these fisheries.

Based on the available data we suggest that a degree of spatial segregation at-sea by age is a better explanation for the observed age-specific susceptibility to bycatch, rather than differences in competitive capacity or experience in avoiding fishing gear. In the southern hemisphere, immature birds disperse further north and spend more time in subtropical waters, whereas adults (especially breeders) are more likely to stay in subAntarctic waters (Bugoni and Furness, 2009; Catry et al., 2013; Olmos, 1997; Phillips et al., 2005; Sullivan et al., 2004; Waugh et al., 1999; Weimerskirch et al., 2014, 2006). This pattern seems to be reflected in the significantly higher mortality of adults in subpolar areas in our analysis, which mainly resulted from the consistent adult-biased bycatch in diverse fisheries across sub-Antarctic waters (Bartle, 1991; Ryan and Box-Hinzen, 1999; Gales et al. 1998, Nel et al., 2002a; Robertson and Bell, 2002; Gandini et al., 1999; Seco-Pon 
et al., 2007; Thompson, 2010a, b). On the other hand, in subtropical areas, where there are often more immatures (Copello et al. 2013, Phillips et al., 2006, 2005; Weimerskirch et al., 2014), our analyses indicated more samples biased to this younger age class (43\%) in comparison to fisheries in sub-Antarctic waters (17\%). Although the proportion of immatures bycaught in subtropical areas is highest during summer (up to 100\%), when most adults return to their breeding areas (Petersen at al., 2010; Ryan et al., 2002), immatures can also predominate in bycatch during winter (Gales et al., 1998; Murray et al., 1993; Neves and Olmos, 1997; Roma et al., 2009). The significantly higher bycatch of adults in trawl and demersal longline fisheries within the subpolar region is likely to reflect the same large-scale pattern, since those fisheries operate in shelf and slope waters closer to colonies (Bartle, 1991; Gandini at al., 1999; Nel et al. 2002a; Robertson et al. $2003,2004)$, whereas pelagic longliners operate in much more pelagic waters and at lower latitudes of the subpolar region (Beck et al., 2013, Gales et al. 1998; Thompson 2010a). This age-specific mortality associated with differential distribution at sea is not exclusive to albatrosses and petrels of the southern hemisphere. A range of other species in both hemispheres, including diving ducks, penguins, alcids, fulmars and gulls showed regional and seasonal patterns of age-specific bycatch likely to reflect differential overlap with fisheries; these seem to be linked to age-related differences in distribution as a consequence of breeding constraints, moult cycles, migration or age-specific foraging strategies (Cardoso et al., 2011; Gandini et al., 1999; Nevins et al., 2004; Phillips et al., 2010; Stempniewicz, 1994; Thompson et al., 1998; Votier et al. 2011). The significant effect of region on age ratios of seabirds bycaught on longlines but not in gillnets may be related to the characteristics of the affected seabird. It is unclear whether the taxa that are at greatest risk from gillnets (alcids, diving ducks) show large-scale age-segregation by latitude, or even if they do, they may not be killed in gillnets in some parts of their range.

\subsubsection{Demographic effects of age-specific bycatch}

Globally, mortality of adults in fisheries is thought to have deleterious effects not just on albatrosses and petrels, but also diving ducks, alcids and penguins (Cardoso et. al, 2011; Darby and Dawson 2000, Smith and Morgan, 2005, Thompson et al., 2010a, 2010b, 1998; Žydelis et al., 2009). In many cases, there is insufficient data on bycatch rates of different age classes to accurately estimate the impacts of, or predict the response to, potential management regimes (including changes in fishing effort distribution, or bycatch mitigation). These problems are exacerbated in the absence of robust data on demographic rates, particularly given the difficulties of disentangling effects of mortality in fisheries from other factors affecting breeding populations, such as environmental changes, depletion of prey stocks, introduced predators, habitat deterioration etc.

Although adult mortality has the most immediate and pronounced negative effect, chronic mortality of immatures can reduce recruitment below the minimum level needed to maintain population stability (Nur and Sydeman, 1999; Prince et al., 1994, Sherley et al. 2015). Juvenile survival in seabirds is normally lower than adults (Nur and Sydeman, 1999), but there is evidence that fisheries can reduce immature survival rates of some species even further. For example, negative trends in juvenile survival of black-browed albatross from South Georgia are correlated with the increase in pelagic longline fishing effort off South Africa (Arnold et al., 2006; Croxall et al., 1998; Tuck et al., 2003), which is the primary destination of young birds from that population (Phillips et al. 2005). Therefore, the higher susceptibility of juveniles to bycatch in pelagic longline fisheries, which are the most widespread and largest-scale of those operating in subtropical waters of the southern hemisphere (Anderson et al., 2011; Tuck et al., 2003), may be contributing to the low immature survival of black-browed and other albatross populations in the Southern Ocean (ACAP 2010b, a, 2009; Croxall et al., 1998; Prince et al., 1994). Indeed, high mortality of immatures in fisheries resulting in depressed recruitment levels appears 
to have been a major contributor to the decline of both black-browed and grey-headed (Thalassarche chrysostoma) albatrosses at South Georgia (Prince et al., 1994).

\subsection{Implications for management and conservation}

Seabirds are the most threatened group of birds; nearly half of the 346 species are known or suspected to be in decline, with one third threatened with extinction, including 17 critically endangered, 35 endangered, 49 vulnerable and 37 near threatened (Croxall et al., 2012), and there has been a 70\% decline in monitored populations between 1950 and 2010 (Paleczny et al., 2015). Bycatch was identified as one of the two greatest threats, and the most pervasive threat at sea (Croxall et al., 2012). Hence, given the frequency and magnitude of both sex- and age-biases in seabird bycatch, and the demographic implications, we strongly recommend much improved data collection on the age and sex of birds killed by fisheries in on-board observing programs at national and international levels. The latter requires concerted and coordinated action by Regional Fishery Management Organisations (RFMOs). In addition to increased on-board observer effort, it is necessary to implement standardized protocols for retrieving carcasses and collecting biological samples to provide high quality information on seabird bycatch; this includes accurate information on sex (Bugoni and Furness, 2009; Fridolfsson and Ellekrer, 1999), age (Bugoni and Furness, 2009; Thompson et al., 2010), and improved attempts to identify provenance (Abbot et al., 2006; Gómez-Díaz \& González-Solís, 2007; Abbot et al., 2014). These approaches are especially urgent in the northern hemisphere - despite high levels of seabird bycatch here, the number of studies reporting age and sex-specific totals is much lower than in the southern hemisphere. Moreover, tracking studies that map the distributions and hence overlap with specific vessels of birds of different age class and sex, throughout the year, will greatly improve ecological risk assessments (Jiménez et al., 2015a; Komorose and Lewison, 2015). Likewise, integrated population models testing the effects of fisheries on seabird demography, including analyses of Potential Biological Removal (PBR), must take sex- and age-specific differences in bycatch rates to avoid underestimation of the PBR and potentially instituting management actions that are insufficient (Dillingham and Fletcher, 2011; Lewison et al., 2012). Together, this information can then be used by regional (i.e. national action plans) and international conservation initiatives (including the Agreement on the Conservation of Albatrosses and Petrels, ACAP), as well as local fisheries management organizations and RFMOs to identify regions and fleets where more prescriptive mitigation measures should be applied, and where monitoring of compliance needs to be more intensive to prevent severe impacts of bycatch on seabird populations (Croxall et al., 2013; Phillips, 2013; Phillips et al., 2016). However, because (1) there is low reliability of bycatch data globally, (2) populations are at risk from different fisheries across large areas, and (3) provenance of bycaught birds is often unknown, incorporating information on sex- and age-biased bycatch in seabird management and conservation remains challenging, and the data must be examined on a case-by-case basis.

\section{Conclusion}

Sex and age biases in seabird bycatch are common features across global fisheries, mainly related to differential at-sea distributions. Overall, bycatch of adults and males was higher in subpolar regions and closer to colonies, whereas immatures and females were caught more frequently in subtropical waters. We found no compelling evidence that differences in sex and age ratios are related to the competitive advantage of males and adults foraging at fishing vessels, or to naivety of young birds around fishing gear. There is clear evidence that differences in capture rates by sex and age have implications for populations that differ from those of unbiased mortality. Despite this, the need to ensure information is obtained on sex and age of bycaught birds has been largely neglected by on- 
board observer programs in national and international fisheries. Given the ubiquity and population-level consequences of such biases, we believe that global efforts to map bycatch and understand their impacts (e.g. Lewison et al., 2014) should include age and sex information wherever possible.

\section{Acknowledgments}

We thank Stuart Bearhop for providing constructive comments on the manuscript, and Hanna Nevins and Peter Ryan for providing valuable literature. We also thank Fabio Olmos for providing pictures of some of the birds composing our figures. This work is part funded via a scholarship to DG from the Sciences Without Borders Program (CNPq/Brazil). The study represents a contribution to the Ecosystems component of the British Antarctic Survey Polar Science for Planet Earth Programme, funded by the Natural Environment Research Council.

\section{References}

Abbott, C.L., Millikin, R.L., Hipfner, M.J., Hatch, S., Ito, M., Watanuki, Y., Burg, T.M., 2014. Genetic structure of rhinoceros auklets, Cerorhinca monocerata, breeding in British Columbia, Alaska and Japan. Mar. Biol. 161: 275-283. http://dx.doi.org/10.1007/s00227-013-2333-2

Abbott, C.L., Double, M.C., Gales, R., Baker, G.B., Lashko, A., Robertson, C.J.R., Ryan, P.G., 2006. Molecular provenance analysis for shy and white-capped albatrosses killed by fisheries interactions in Australia, New Zealand, and South Africa. Conserv. Genet. 7: 531-542. http://dx.doi.org/10.1007/s10592-005-9064-y

ACAP - Agreement on the Conservation of Albatrosses and Petrels, 2009. ACAP Species assessment: Campbell Albatross Thalassarche impavida. http://www.acap.aq/acap-species

ACAP - Agreement on the Conservation of Albatrosses and Petrels, 2010a. ACAP Species assessment: Black-browed Albatross Thalassarche melanophris. http://www.acap.aq/acap-species

ACAP - Agreement on the Conservation of Albatrosses and Petrels, 2010b. ACAP Species assessment: Grey-headed Albatross Thalassarche chrysostoma. http://www.acap.aq/acap-species

Anderson, O.R.J., Small, C.J., Croxall, J.P., Dunn, E.K., Sullivan, B.S., Yates, O., Black, A., 2011. Global seabird bycatch in longline fisheries. Endanger. Species Res. 14, 91-106. http://dx.doi.org/10.3354/esr00347

Arnold, M.J., Brault, S., Crowall, J.P., 2006. Albatross population in peril: a population trajectory for black-browed albatrosses at South Georgia. Ecol. Appl. 16, 419-432. http://www.jstor.org/stable/40061809

Awkerman, J.A., Huyvaert, K.P., Mangel, J., Shigueto, J.A., Anderson D.J., 2006. Incidental and intentional catch threatens Galápagos waved albatross. Biol. Conserv. 133, 483-489. http://dx.doi.org/10.1016/j.biocon.2006.07.010

Anderson, D. J., Porter, E. T., Ferre, E. D., 2077. Non-breeding Nazca boobies (Sula Granti) show social and sexual interest in chicks: behavioural and ecological aspects. Behav. 141, 959-977. http://dx.doi.org/10.1163/1568539042360134

Awkerman, J.A., Westbrock, M.A., Huyvaert, K.P., Anderson D.J., 2007a. Female-biased sex ratio arises after parental care in the sexually dimorphic waved albatross (Phoebastria irrorata). Auk 124, 1336-1346. http://www.jstor.org/stable/25150393

Awkerman, J.A., Hobson, K.A., Anderson, D.J., 2007b. Isotopic (d15N and d13C) evidence for intersexual foraging differences and temporal variation in habitat use in waved albatrosses. Can. J. Zool. 85, 273-279. http://dx.doi.org/10.1139/Z06-202 
Barbraud, C., Rolland, V., Jenouvrier, S., Nevoux, M., Delord, K., Weimerskirch, H., 2012. Effects of climate change and fisheries bycatch on Southern Ocean seabirds: a review. Mar. Ecol. Prog. Ser. 454, 285-307. http://dx.doi.org/10.3354/meps09616

Barnes, K.N., Ryan, P.G., Boix-Hinzen, C., 1997. The impact of the Hake Merluccius spp. longline fishery off South Africa on procellariiform seabirds. Biol. Conserv. 82, 227-234. http://dx.doi.org/10.1016/S0006-3207(97)00020-7

Bartle, J.A., 1990. Sexual segregation of foraging zones in procellariiform birds: implications of accidental capture on commercial fishery longlines of Grey Petrels (Procellaria cinerea). Notornis 37, 146-150. http://notornis.osnz.org.nz/system/files/Notornis 372 146.pdf

Bartle, J.A., 1991. Incidental capture of seabirds in the New Zealand subantarctic squid trawl fishery, 1990. Bird Conserv. Int. 1, 351-359. http://dx.doi.org/10.1017/S0959270900000708

Beck J., Nevins, H., Hester, M., 2013. Necropsy findings from Seabird Bycatch in Hawaii and Alaska Longline Fisheries: Examinations conducted in 2013. Final 2013 Report: Oikonos - Ecosystem Knowledge. NOAA Order No. AB133F-10-SE-3805. 11 p.

Blanchard, P., Hanuise, N., Dano, S., Weimerskirch, H., 2007. Offspring sex ratio in relation to parental structural size and body condition in the long-lived wandering albatross (Diomedea exulans). Behav. Ecol. Sociobiol. 61, 767-773. http://dx.doi.org/10.1007/s00265-006-0307-9

Bretagnole, V., Thibault, J., 1995. Method for Sexing Fledglings in Cory's Shearwaters and Comments on Sex-Ratio Variation. Auk 112, 785-790. http://www.jstor.org/stable/4088700

Bregnballe, T., Frederiksen, M., 2006. Net-entrapment of great cormorants Phalacrocorax carbo sinensis in relation to individual age and population size. Wildl. Biol.. 12, 143150. http://dx.doi.org/10.2981/0909-6396(2006)12[143:NOGCPC]2.0.CO;2

Burg, T., 2008. Genetic analysis of Wandering Albatrosses killed in longline fisheries off the east coast of New Zealand. Aquat. Conserv. 17, S93-S101. http://dx.doi.org/10.1002/aqc.907

Bugoni, L., Furness, R.W., 2009. Age composition and sexual size dimorphism of albatrosses and petrels off Brazil. Mar. Ornithol. 37, 253-260. http://www.marineornithology.org/PDF/37_3/37_3_253-260.pdf

Bugoni, L., Griffiths, K., Furness, R.W., 2011. Sex-biased incidental mortality of albatrosses and petrels in longline fisheries: differential distributions at sea or differential access to baits mediated by sexual size dimorphism? J. Ornithol. 152, 261-268. http://dx.doi.org/10.1007/s10336-010-0577-x

Cardoso, L.G., Bugoni, L., Mancini, P.L., Haimovici, M., 2011. Gillnet fisheries as a major mortality factor of Magellanic penguins in wintering areas. Mar. Pollut. Bull. 62, 840-844. http://dx.doi.org/10.1016/j.marpolbul.2011.01.033

Catry, P., Lemos, R., Brickle, P., Phillips, R.A., Matias, R., Granadeiro, J.P., 2013. Predicting the distribution of a threatened albatross: the importance of competition, fisheries and annual variability. Prog. Oceanogr. 110, 1-10. http://dx.doi.org/10.1016/j.pocean.2013.01.005

Cuthbert, R., Hilton, G., Ryan, P., Tuck, G.N., 2005. At-sea distribution of breeding Tristan albatrosses Diomedea dabbenena and potential interactions with pelagic longline fishing in the South Atlantic Ocean. Biol. Conserv. 121, 345-355. http://dx.doi.org/10.1016/j.biocon.2004.05.007

Copello, S., Seco-Pon, J.P., Favero, M., 2013. Use of marine space by Black-browed albatrosses during the non-breeding season in the Southwest Atlantic Ocean. Estuar. Coast. Shelf Sci. 123, 34-38. doi: 10.1016/j.ecss.2013.02.016

Croxall, J.P., Prince, P.A., 1990. Recoveries of Wandering Albatrosses Diomedea exulans ringed at South Georgia 1958-1986. Ringing Migr. 11, 43-51. http://dx.doi.org/ 10.1080/03078698.1990.9673960 
Croxall, J.P., Butchart, S.H.M., Lascelles, B., Stattersfield, A.J., Sullivan, B., Symes, A., Taylor, P., 2012. Seabird conservation status, threats and priority actions: a global assessment. Bird Conserv. Int. 22: 1-34. http://dx.doi.org/10.1017/S0959270912000020

Croxall, J., Small, C., Sullivan, B., Wanless, R., Frere, E., Lascelles, B., Ramirez, I., Sato, M., Yates, 0., 2013. Appropriate scales and data to manage seabird-fishery interactions: comment on Torres et al. 2013. Mar. Ecol. Prog. Ser. 493: 297-300. http://dx.doi.org/10.3354/meps10600

Croxall, J.P., Prince, P.A., Rothery, P., Wood, A.G., 1998. Population changes in albatrosses at South Georgia, in: Robertson, G., Gales, R., (Eds.), Albatross Biology and Conservation, Surrey Beatty and Sons, Chipping Norton, pp. 69-83.

Darby , J.T., Dawson, M.S., 2000. Bycatch of yellow-eyed penguins (Megadyptes antipodes) in gillnets in New Zealand waters 1979-1997. Biol. Conserv. 93, 327-332. http://dx.doi.org/10.1016/S0006-3207(99)00148-2

Delord, K., Gasco, N., Weimerskirch, H., Barbraud, C., Micol, T., 2005. Seabird mortality in the Patagonian Toothfish longline fishery around Crozet and Kerguelen Islands, 2001-2003. CCAMLR Science. 12, 53-80. http://www.ccamlr.org/en/system/files/science_journal_papers/04delordetal.pdf

Delord, K., Besson, D., Barbraud, C., Weimerskirch, H., 2008. Population trends in a community of large Procellariiforms of Indian Ocean: Potential effects of environment and fisheries interactions. Biol. Conserv. 141, 1840-1856. http://dx.doi.org/10.1016/j.biocon.2008.05.001

Delord, K., Barbraud, C., Weimerskirch, H., 2010. Multivariate effects on seabird bycatch in the legal Patagonian Toothfish longline fishery around Crozet and Kerguelen Islands. Polar Biol. 33,367-378. http://dx.doi.org/10.1007/s00300-009-0713-3

Dillinghan, P.W., Fletcher, D., 2011. Potential biological removal of albatrosses and petrels with minimal demographic information. Biol. Conserv. 144: 1885-1894. http://dx.doi.org/10.1016/j.biocon.2011.04.014

Donald, P.F., 2007. Adult sex ratios in wild bird populations. Ibis 149: 671-692. http://dx.doi.org/ 10.1111/j.1474-919X.2007.00724.x

Fayet, A. L., Freeman, R., Shoji, A., Padget, O., Perrins, C. M., Guilford, T., 2015. Lower foraging efficiency in immatures drives spatial segregation with breeding adults in a long-lived pelagic seabird. Anim. Behav. 110: 79-89. http://dx.doi.org/10.1016/i.anbehav.2015.09.008

Fridolfsson, A. K., Ellegren, H., 1999. A simple and universal method for molecular sexing of non-ratite birds. J. Avian Biol. 30, 116-121. http://www.jstor.org/stable/3677252

Gales, R., Brothers, N., Reid, T., 1998. Seabird mortality in the Japanese tuna longline fishery around Australia, 1988-1995. Biol. Conserv. 86, 37-56. http://dx.doi.org/10.1016/S0006-3207(98)00011-1

Gandini, P.A., Frere, E., 2006. Spatial and temporal patterns in the bycatch of seabirds in the Argentinean longline fishery. Fish. Bull. 104, 482-485. URL: http://fishbull.noaa.gov/1043/gandini.pdf

Gandini, P.A., Frere, E., Pettovello, A.D., Cedrola, P.V., 1999. Interaction between Magellanic Penguins and Shrimp Fisheries in Patagonia, Argentina. Condor. 101, 783-789. http://www.jstor.org/stable/1370065

Gómez-Díaz, E., González-Solís, J. 2007. Geographic assignment of seabirds to their origin: combining morphologic, genetic, and biogeochemical analyses. Ecol. Appl. 17, http://dx.doi.org/1484-1498./doi/10.1890/06-1232.1

Hall, M.A., Alverson, D.L., Metulzas, K.I., 2000. By-Catch: Problems and Solutions. Mar. Pollut. Bull., 41: 204-219. http://dx.doi.org/10.1016/S0025-326X(00)00111-9

Halpern, B.S., Walbridge, S., Selkoe, K.A., Kappel, C.V., Micheli, F., D’Grosa, C., Bruno, J.F., Casey, K.S., Ebert, C., Fox, H.E., Fugita, R., Heinemann, D., Lenihan, H.S., Madin, 
E.M.P., Perry, M.T., Selig, E.R., Spalding, M., Steneg, R., Watson, R., 2008. A global map of human impact on marine ecosystem. Science 319, 948-952. http://dx.doi.org/ 10.1126/science.1149345

Hedd, A., Montevecchi, W.A., Phillips, R.A., Fifield, D.A., 2014. Seasonal Sexual Segregation by Monomorphic Sooty Shearwaters Puffinus griseus Reflects Different Reproductive Roles during the Pre-Laying Period. PLoS ONE 9, e85572. http://dx.doi.org/ 10.1371/journal.pone.0085572

Huyvaert, K.P., Anderson, D.J., Jones, T.C., Duan, W., Parker, P.G., 2000. Extra-pair paternity in waved albatrosses. Mol. Ecol. 9, 1415-1419. http://dx.doi.org/10.1046/j.1365294x.2000.00996.x

Jackson, J.B.C., Kirby, M.X., W.H. Berger, Bjorndal, K.A., Botsford, L.W., Bourque, B.J., Bradbury, R.H., Cooke, R., Erlandson, J., Estes, J.A., Huges, T.P., Kidwell, S., Lange, C.B., Lenihan, H.S., Pandolfi, J.A., Peterson, C.H., Steneck, R.S., Tegner, M.J., Warner, R.R., 2001. Historical overfishing and the recent collapse of coastal ecosystems. Science 293, 629-637. http://dx.doi.org/10.1126/science.1059199

Jiménez-Uzcátegui, G., Mangel, J., Alfaro-Shigueto, J., Anderson, D., 2006. Fishery bycatch of the Waved Albatross Phoebastria irrorata, a need for implementation of agreements. Galapagos Res. 64: 7-9. http://www.darwinfoundation.org/datazone/media/pdf/64/GR_64_2006_\%20Ji menez-Uzcategui_et_al_Waved_Albatross.pdf

Jiménez, S., Domingo, A., Abreu, M., Brazeiro, A., 2012. Bycatch susceptibility in pelagic longline fisheries: are albatrosses affected by the diving behaviour of mediumsized petrels? Aquat. Conserv. 22, 436-445. http://dx.doi.org/doi/10.1002/aqc.2242

Jiménez, S., Domingo, A., Abreu, M., Brazeiro, Defeo, O., Wood, A.G., Froy, H., Xavier, J.C., Phillips, R.A., 2015a. Sex-related variation in the vulnerability of wandering albatrosses to pelagic longline fleets. Anim. Conserv. 19: 281-295. http://dx.doi.org/ 10.1111/acv.12245

Jiménez, S., Alejandro, M., Abreu, M., Forselledo, R., Pereira, A., Domingo, A., 2015b. Molecular analysis suggests the occurrence of Shy Albatross in the south-western Atlantic Ocean and its by-catch in longline fishing. Emu 115, 58-62. http://dx.doi.org/ 10.1071/MU13105

Jiménez, S., Domingo, A., Brazeiro, A., Defeo, O., Abreu, M., Forselledo, R., Phillips, R.A., 2016. Sexual size dimorphism, spatial segregation and sex-biased bycatch of southern and northern royal albatrosses in pelagic longline fisheries. Antarct. Sci., First view. http://dx.doi.org/10.1017/S0954102016000493

Langston, N.E., Rohwer S., 1995. Unusual pattern of incomplete primary moult in Laysan and Black-footed albatrosses. Condor 97, 1-19. http://www.jstor.org/stable/1368978

Komoroske, L.M., Lewison, R.L., 2015. Addressing fisheries bycatch in a changing world. Front. Mar. Sci. 2, 83. http://dx.doi.org/10.3389/fmars.2015.00083

Lewison, R.L., Crowder, L.B., Wallace, B.P., Moore, J.E., Cox, T., Zydelis, R., MacDonald, S., DiMatteo, A., Dunn, D.C., Cot, C.Y., Bjorkland, R., Kelez, S., Soykan, C., Stewart, K.R., Sims, M., Boustany, A., Read, A.J., Halpin, P., Nichols, W.J., Safina, C., 2014. Global patterns of marine mammal, seabird, and sea turtle bycatch reveal taxa-specific and cumulative megafauna hotspots. Proc. Natl. Acad. Sci. USA 111, 5271-5276. http://dx.doi.org/10.1073/pnas.1318960111

Lewison, R.L., Crowder, L.B., Read, A.J., Freeman, S.A., 2004. Understanding impacts of fisheries bycatch on marine megafauna. Trends Ecol. Evol. 19, 598-604. http://dx.doi.org/10.1016/j.tree.2004.09.004

Lewison, R.L., Oro, D., Godley, B.J., Underhill, L., Bearhop, S., Wilson, R.P., Ainley, D., Arcos, J.M., Boersma, P.D., Borboroglu, P.G., Boulinier, T., Frederiksen, M., Genovart, M., González-Solís, J., Green, J.A., Grémillet, D., Hamer, K.C., Hilton, G.M., Hyrenbach, K.D., Martínez-Abraín, A., Montevecchi, W.A., Phillips, R.A., Ryan, P.G., Sagar, P., 
Sydeman, W.J., Wanless, S., Watanuki, Y., Weimerskirch, H., Yorio, P., 2012.

Research priorities for seabirds: improving conservation and management in the 21st century. Endanger. Species Res. 17, 93-121. http://dx.doi.org/10.3354/esr00419

Maree, B.A, Wanless, R,M, Fairweather, T.P., Sullivan, B.J., Yates, O., 2014. Significant reductions in mortality of threatened seabirds in a South African trawl fishery. Anim. Conserv. 17: 520-529. http://dx.doi.org/ 10.1111/acv.12126

Mills, M.S. L., Ryan, P.G., 2005. Modelling impacts of long-line fishing: what are the effects of pair-bond disruption and sex-biased mortality on albatross fecundity? Anim. Conserv. 8, 359-367. http://dx.doi.org/10.1017/S1367943005002386

Montevecchi, W.A., 2002. Interactions between fisheries and seabirds, in: Schreiber, E.A., Burger, J. (eds.), Biology of Marine Birds, CRC Press, Boca Raton, pp. 527-558.

Murray, T.E., Battle, J.A., Kalish, S.R., Taylor, P.R., 1993. Incidental capture of seabirds by Japanese Southern Bluefin Tuna longline vessels in New Zealand waters, 19881992. Bird Conserv. Int. 3, 181-210. http://dx.doi.org/ http://dx.doi.org/10.1017/S0959270900000897

Nel, D.C., Ryan, P.G., Watkins, B.P., 2002a. Seabird mortality in the Patagonian Toothfish longline fishery around Prince Edward Island, 1996-2000. Antarct. Sci. 14, 151161. http://dx.doi.org/10.1017/S0954102002000718

Nel, D.C., P.G. Ryan, Nel, J.L., Klages, N.T.W., Wilson, R.P., Robertson, G., Tuck, J.N., 2002b. Foraging interactions between Wandering Albatrosses Diomedea exulans breeding on Marion Island and long-line fisheries in the southern Indian Ocean. Ibis 144, E141-E154. http://dx.doi.org/10.1046/j.1474-919X.2002.00092.x

Neves, T., Olmos, F., 1998. Albatross mortality in fisheries off the coast of Brazil, in: Robertson, G., Gales, R., (Eds.), Albatross Biology and Conservation, Surrey Beatty and Sons, Chipping Norton, pp. 214-219.

Nevins, H.N., 2004. Diet, demography and behaviour of Common Murre (Uria aalgae) in Central California, Master Thesis, San Francisco State University, San Francisco.

Nur, N., Sydeman, W.J., 1999. Demographic Processes and Population Dynamic Models of Seabirds. Curr. Ornithol. 15, 149-188. http://dx.doi.org/10.1007/978-1-47574901-4_4

Olmos, F., 1997. Seabirds attending bottom long-line fishing off Southeastern Brazil. Ibis 139, 685-691. http://dx.doi.org/10.1111/j.1474-919X.1997.tb04692.x

Österblom, H., Fransson, T., Olsson, O., 2002. Bycatches of common guillemot (Uria aalge) in the Baltic Sea gillnet fishery. Biol. Conserv. 105, 309-319. http://dx.doi.org/10.1016/S0006-3207(01)00211-7

Petersen, S.L., Honig, M.B., Ryan, P.G., Underhill, L.G., 2010. Seabird bycatch in the pelagic longline fishery off southern Africa. Afr. J. Mar. Sci. 31, 191-204. http://dx.doi.org/10.2989/AJMS.2009.31.2.7.879

Paleczny, M., Hammill, E., Karpouzi V, Pauly, D., 2015. Population Trend of the World's Monitored Seabirds, 1950-2010. PLoS ONE 10(6), e0129342.

Phillips, R.A., Gales, R., Baker, G.B., Double, M.C., Favero, M., Quintana, F., Tasker, M.L., Weimerskirch, H., Uhart, M., Wolfaardt, A., 2016. The conservation status and priorities for albatrosses and large petrels. Biol. Conserv. 201, 169-183. http://dx.doi.org/10.1016/j.biocon.2016.06.017 0006-3207

Phillips, R., 2013. Requisite improvements to the estimation of seabird by-catch in pelagic longline fisheries. Anim. Conserv. 16: 157-158. http://dx.doi.org/10.1111/acv.12042

Phillips, R.A., McGill, R., Dawson, D., Bearhop, S., 2011. Sexual segregation in distribution, diet and trophic level of seabirds: insights from stable isotope analysis. Mar. Biol. 158, 2199-2208. http://dx.doi.org/10.1007/s00227-011-1725-4

Phillips, E.M., Nevins, H.M., Hatch, S.A., Ramey, A.M., Miller, M.A., Harvey, J.T., 2010. Seabird bycatch in Alaska demersal longline fishery trials: A demographic summary. Mar. 
Ornithol. 38, 111-117. http://marineornithology.org/PDF/38 2/38 2 111117.pdf

Phillips, R.A., Silk, J.R.D., Croxall, J.P., Afanasyev, V., 2006. Year-round distribution of whitechinned petrels from South Georgia: Relationships with oceanography and fisheries. Biol. Conserv. 129, 336-334. http://dx.doi.org/10.1016/j.biocon.2005.10.046

Phillips, R.A., Silk, J.R.D., Croxall, J.P., Afanasyev, V., Bennett, V.J., 2005. Summer distribution and migration of nonbreeding albatrosses: individual consistencies and implications for conservation. Ecology 81, 2386-2396. http://dx.doi.org/10.1890/04-1885

Phillips R.A., Silk, J.R.D., Phalan, B., Catry, P., Croxall, J.P., 2004. Seasonal sexual segregation in two Thalassarche albatross species: competitive exclusion, reproductive role specialization or foraging niche divergence? Proc. R. Soc. B 271, 1283-1291. http://dx.doi.org/10.1098/rspb.2004.2718

Piatt, J.F., Gould, P.J., 1994. Dispersal and drift-net mortality of endangered Japanese murrelets. Auk 111: 953-961. http://dx.doi.org/10.2307/4088827

Poncet, S., Robertson, G., Phillips, R.A., Lawton, K., Phalan, B., Trathan, P.N., Croxall, J.P., 2006. Status and distribution of wandering, black-browed and grey-headed albatrosses breeding at South Georgia. Polar Biol. 29, 772-781. http://dx.doi.org/10.1007/s00300-006-0114-9

Prince, P.A., Rothery, P., Croxall, J.P., Wood, A.G., 1994. Population dynamics of Blackbrowed and Grey-headed Albatrosses at Bird Island, South Georgia. Ibis 136, 50 71. http://dx.doi.org/10.1111/j.1474-919X.1994.tb08131.x

R Development Core Team, 2011. R: A Language and Environment for Statistical Computing, The R Foundation for Statistical Computing, Vienna. http://www.Rproject.org/

Reid, T.A., Sullivan, B.J., Pompert, J., Enticott, J.W., Black, A.D., 2004. Seabird mortality associated with Patagonian Toothfish (Dissostichus eleginoides) longliners in Falkland Islands waters. Emu 104, 317-325. http://dx.doi.org/10.1071/MU030020158-4197/04/040317

Robertson, C.J.R., 2000. Autopsy report for seabirds killed and returned from New Zealand fisheries, 1 January 1998 to 30 September 1998. Conservation Advisory Science Notes No. 294, Department of Conservation, Wellington. http://www.doc.govt.nz/Documents/science-and-technical/casn294.pdf

Robertson, C.J.R., Bell. C., 2002. Autopsy report for seabirds killed and returned from New Zealand fisheries, 1 October 1998 to 30 September 1999: Birds returned by Ministry of Fisheries observers to the Department of Conservation, DOC Science Internal Series 28, Department of Conservation, Wellington. http://www.doc.govt.nz/documents/science-and-technical/DSIS28.pdf

Robertson, C.J.R., Bell, E., Scofield, P., 2004. Autopsy report for seabirds killed and returned from New Zealand fisheries, 1 October 2001 to 30 September 2002: Birds returned by Ministry of Fisheries observers to the Department of Conservation, DOC Science Internal Series 155, Department of Conservation, Wellington. http://www.doc.govt.nz/documents/science-and-technical/dsis155.pdf

Robertson, C.J.R., Bell, E., Scofield, P., 2003. Autopsy report for seabirds killed and returned fromNew Zealand fisheries, 1 October 2000 to 30 September 2001: Birds returned by Ministry of Fisheries observers to the Department of Conservation, DOC Science Internal Series 96, Department of Conservation, Wellington. http://doc.govt.nz/documents/science-and-technical/DSIS96.pdf

Rolland, V.,H. Weimerskirch, H., Barbraud, C. 2010. Relative influence of fisheries and climate on the demography of four albatross species. Glob. Chang. Biol. 16, 1910-1922. http://dx.doi.org/10.1111/j.1365-2486.2009.02070.x

Roma, C.R., 2009. Composição sexual e etária do Albatroz-de-sobrancelha-negra Thalassarche melanophrys [sic] e da Pardela-preta Procellaria aequinoctialis 
(Ordem: Procellariiformes) do Sul-Sudeste do Brasil. Master dissertation, Unimonte, Santos.

Ryan, P.G., Boix-Hinzen, C., 1999. Consistent male-biased seabird mortality in the Patagonian Toothfish longline fishery. Auk 116, 851-854. http://www.jstor.org/stable/4089350

Ryan, P.G., Keith, D.G., Kroese, M., 2002. Seabird bycatch by tuna longline fisheries off Southern Africa, 1998-2000. S. Afr. J. mar. Sci. 24, 103-110. http://dx.doi.org/10.2989/025776102784528565

Schreiber, E. A., Burger, J. 2002. Biology of Marine Birds, CRC Press, Boca Raton.

Shealer, D.A. 2002. Foraging behaviour and food of seabird. in: Schreiber, E. A., Burger J. (eds.), Biology of Marine Birds, CRC Press, Boca Raton, pp. 137-178.

Sherley, R.B., Winkwer, J., Altwegg, van der Lingen, C.D., Votier, S.C., Crawford, R.J.M., 2015. Bottom-up effects of a no-take zone on endangered penguin demographics. Biol. Lett. 11(7), 20150237. http://dx.doi.org/10.1098/rsbl.2015.0237

Seco-Pon, J.P., Gandini, P.A., Favero, M., 2007. Effect of longline configuration on seabird mortality in the Argentine semi-pelagic Kingclip Genypterus blacodes fishery. Fish. Res. 85, 101-105. http://dx.doi.org/10.1016/j.fishres.2007.01.002

Simeone, A., Bernal, M., Meza, J., 1999. Incidental mortality of Humboldt Penguins Spheniscus humboldti in gillnets, Central Chile. Mar. Ornithol. 27, 157-161. http://www.marineornithology.org/PDF/27/27 19.pdf

Smith, J.L., Morgan, H.K., 2005. An assessment of seabird bycatch in longline and net fisheries in British Columbia. Technical Report Series No. 401, Pacific and Yukon Region, Canadian Wildlife Service, Delta, URL: http://birdsmith.ca/papers/SmithMorgan 2005.pdf

Stauss, C., Bearhop, S., Bodey, T.W., Garthe, S., Gunn, C., Grecian, W.J., Inger, R., Knight, M.E., Newton, J., Patrick, S.C., Phillips, R.A., Waggitt, J.J., Votier, S.C., 2012. Sex-specific foraging behaviour in northern gannets Morus bassanus: Incidence and implications. Mar. Ecol. Prog. Ser. 457, 151-162. http://dx.doi.org/ $10.3354 /$ meps09734

Stempniewicz, L., 1994. Marine birds drowning in fishing nets in the Gulf of Gdańsk (Southern Baltic): numbers, species composition, age and sex structure. Ornis Svecica 4, 123-132.

Sullivan, B., Reid, T., Huin, N., Neves, T., Warlich, R., 2004. Colour marking of fledgling black-browed albatross on Steeple Jason Island, Falklands Conservation. http://www.falklandsconservation.com/news/54-colour-marking-of-fledglingblack-browed-albatross

Sullivan, B., Reid, T., Bugoni, L., 2006. Seabird mortality on factory trawlers in the Falkland Islands and beyond. Biol. Conserv. 131, 495-504. http://dx.doi.org/10.1016/j.biocon.2006.02.007

Taylor, S.S., Leonard, M., 2001. Aggressive nest intrusions by male Humboldt penguins. Condor 103, 162-165. http://dx.doi.org/10.1650/00105422(2001)103[0162:ANIBMH]2.0.CO;2

Thiers, L., Delord, K., Barbraud, C., Phillips, R.A., Pinaud, D., Weimerskirch, H., 2014. Foraging zones of the two sibling species of giant petrels in the Indian Ocean throughout the annual cycle: implication for their conservation. Mar. Ecol. Prog. Ser. 499, 233-248. http://dx.doi.org/10.3354/meps10620

Thompson, D.R., 2010a. Autopsy report for seabirds killed and returned from observed New Zealand fisheries: 1 October 2006 to 30 September 2007. DOC Marine Conservation Services 3. Department of Conservation, Wellington. http://www.doc.govt.nz/Documents/science-and-technical/dmcs3entire.pdf

Thompson, D.R., 2010b. Autopsy report for seabirds killed and returned from observed New Zealand fisheries: 1 October 2008 to 30 September 2009. DOC Marine Conservation Services Series 6. Department of Conservation, Wellington. http://www.doc.govt.nz/Documents/science-and-technical/dmcs6entire.pdf 
Thompson, D.R., 2009. Autopsy report for seabirds killed and returned from observed New Zealand fisheries: 1 October 2005 to 30 September 2006. DOC Marine Conservation Services 2. Department of Conservation, Wellington.

Thompson, C.W., Wilson, M.L., Pierce, D.J., DeGhetto, D., 1998. Population characteristics of Common Murres and Rhinoceros Auklets entangled in gillnets in Puget Sound, Washington, from 1993 to 1994. Northwest. Nat. 79, 77-91. http://www.jstor.org/stable/3536837

Trebilco, R., Gales, R., Lawrence, E., Alderman, R., Robertson, G., Baker, G.B., 2011. Characterizing seabird bycatch in the eastern Australian tuna and billfish pelagic longline fishery in relation to temporal, spatial and biological influences. Aquat. Conserv. 20, 531-542. http://dx.doi.org/10.1002/aqc.1115

Tuck, G.N., Polacheck, T., Bulman, C.M., 2003. Spatio-temporal trends of longline fishing effort in the Southern Ocean and implications for seabird bycatch. Biol. Conserv. 114, 1-27. http://dx.doi.org/10.1016/S0006-3207(02)00378-6

Uhlmann, S., Fletcher, D., Moller, H., 2005. Estimating incidental takes of shearwaters in driftnet fisheries: lessons for the conservation of seabirds. Biol. Conserv. 123, 151163. http://dx.doi.org/10.1016/j.biocon.2004.11.003

Velando, A., Graves, J. Ortega-Ruano, J.E., 2002. Sex ratio in relation to timing of breeding, and laying sequence in a dimorphic seabird. Ibis 144, 9-16. http://dx.doi.org/ 10.1046/j.0019-1019.2001.00002.x

Votier, S.C., Grecian, W.J., Patrick, S., Newton J., 2011 Inter-colony movements, at-sea behaviour and foraging in an immature seabird: results from GPS-PPT tracking, radio-tracking and stable isotope analysis. Mar. Biol.158, 355-362. http://dx.doi.org/10.1007/s00227-010-1563-9

Votier S.C., Bicknell A., Cox, S.L., Scales, K.L., Patrick, S.C., 2013. A Bird's Eye View of Discard Reforms: Bird-Borne Cameras Reveal Seabird/Fishery Interactions. PLoS ONE 8, e57376. http://dx.doi.org/10.1371/journal.pone.0057376

Waugh, S.M., Sagar, P.M., Cossee, R.O., 1999. New Zealand Black-browed Albatross Diomedea melanophrys impavida and Grey-headed Albatross D-chrysostoma banded at Campbell Island: Recoveries from the South Pacific region. Emu 99, 2935.

Waugh, S.M., MacKenzie, D.I., Fletcher, D., 2008. Seabird bycatch in New Zealand trawl and longline fisheries, 1998-2004. Pap. proc. R. Soc. Tasmania 142, 45-66. https://www.stats.otago.ac.nz/webdata/resources/david_fletcher/Waugh_et_al_2 008.pdf

Weimerskirch, H., Jouventin, P., 1987. Population dynamics of the wandering albatross, Diomedea exulans, of the Crozet Islands: causes and consequences of the population decline. Oikos 49, 315-322. URL: http://www.jstor.org/stable/35657

Weimerskirch. H., Akesson, S., Pinaud, D., 2006. Postnatal dispersal of wandering albatrosses Diomedea exulans: implications for the conservation of the species. J. Avian Biol. 37, 23-28. http://dx.doi.org/10.1111/j.2006.0908-8857.03675.x

Weimerskirch, H., J. Lallemand, Martin, J. 2005. Population sex ratio variation in a monogamous long-lived bird, the wandering albatross. J. Anim. Ecol. 74, 285-291. http://dx.doi.org/10.1111/j.1365-2656.2004.00922.x

Weimerskirch, H., Cherel, Y., Delord, K., Jaeger, A., Patrick, S.C., Riotte-Lambert, L., 2014. Lifetime foraging patterns of the wandering albatross: Life on the move! J. Exp. Mar. Biol. Ecol. 450, 68-78. http://dx.doi.org/10.1016/j.jembe.2013.10.021

Žydelis, R., Bellebaum, J., Österblom, H., Vetemaa, M., Schirmeister, B., Stipniece, A., M., Dagys, van Eerden, M., Garthe, S., 2009. Bycatch in gillnet fisheries - An overlooked threat to waterbird populations. Biol. Conserv. 142, 1269-1281. http://dx.doi.org/10.1016/j.biocon.2009.02.025

Žydelis, R., Small, C., French, G., 2013. The incidental catch of seabirds in gillnet fisheries: A global review. Biol. Conserv. 162: 76-88. http://dx.doi.org/10.1016/j.biocon.2013.04.002 
1001

1002

1003

1004

1005

1006

1007

1008

1009

1010

1011

1012

1013

1014

1015

1016

1017

1018

1019

1020

1021

Zuur, A.F., Ieno, E.N., Walker, N.J., Saveliev, A.A., Smith, G., 2009. Mixed Effects Models and Extensions in Ecology with R, Springer, New York. 


\section{TABLES}

Table 1. List of the studies $(n=44)$ reporting sex and age composition of seabird bycaught in fisheries, with information on the number of taxa with data $(\mathrm{N})$, type of fishery (PLL, pelagic longline; DLL, demersal longline; TRA, trawl; GIL, gillnet; PND, pound net; INT, intentional), region (SUBANT: sub-Antarctic; SUBARC: sub-Arctic; SUBTRS, subtropical southern; SUBTRN, subtropical northern; TROPIC, tropical), area, and year of the bycatch.

\begin{tabular}{|c|c|c|c|c|c|c|c|}
\hline Reference & $\begin{array}{l}\mathrm{N} \\
\text { species }\end{array}$ & $\begin{array}{l}\mathrm{N} \\
\text { sexed }\end{array}$ & $\begin{array}{l}\mathrm{N} \\
\text { aged }\end{array}$ & Fishery & Region & Area & $\begin{array}{l}\text { Bycatch } \\
\text { year }\end{array}$ \\
\hline Jiménez et al., 2016 & 2 & 128 & 0 & PLL & SUBTRS & Uruguay & 2004-2012 \\
\hline Jiménez et al., 2015a & 1 & 49 & 116 & PLL & SUBTRS & Uruguay & $1999-2012$ \\
\hline Jiménez et al., 2015b & 1 & 28 & 28 & PLL & SUBTRS & Uruguay & $2008-2011$ \\
\hline Beck et al., 2013 & 4 & 822 & 694 & DLL, PLL & SUBARC, SUBTRN & Hawaii, Alaska & $2007-2013$ \\
\hline Trebilco et al., 2011 & 1 & 233 & 89 & PLL & SUBTRS & Australia & 2001-2006 \\
\hline Cardoso et al., 2011 & 1 & 0 & 20 & GIL & SUBTRS & Brazil & 2009 \\
\hline Phillips et al., 2010 & 4 & 365 & 348 & DLL & SUBARC & Alaska & 2005 \\
\hline Petersen et al., 2010 & 3 & 935 & 1175 & PLL & SUBTRS & South Africa & 1998-2005 \\
\hline Delord et al., 2010 & 1 & 5189 & 0 & DLL & SUBANT & Kerguelen & $2003-2006$ \\
\hline Thompson, 2010a & 7 & 312 & 327 & PLL, TRA & SUBANT, SUBTRS & New Zealand & 2006-2007 \\
\hline Thompson, 2010b* & 7 & 361 & 367 & PLL, TRA & SUBANT, SUBTRS & New Zealand & 2008-2009 \\
\hline Thompson et al., 2009 & 4 & 308 & 311 & DLL, PLL, TRA & SUBANT & New Zealand & $2005-2006$ \\
\hline Roma, 2009 & 1 & 100 & 67 & PLL & SUBTRS & Brazil & $2006-2008$ \\
\hline Burg, 2008 & 1 & 27 & 0 & PLL & SUBANT, SUBTRS & New Zealand & 1997 \\
\hline Seco-Pon et al., 2007 & 2 & 74 & 18 & DLL & SUBANT & Argentina & 2005 \\
\hline Gandini and Frere, 2006 & 2 & 31 & 0 & DLL & SUBANT & Argentina & $200-2001$ \\
\hline Awkerman et al.. 2006 & 1 & 33 & 0 & PLL, GIL, INT & TROPIC & Peru & 2005 \\
\hline Bregnballe and Frederiksen, 2006 & 1 & 0 & 289 & PND & SUBARC & North Sea & 1983-1992 \\
\hline Jiménez-Uzcátegui et al., 2006 & 1 & 0 & 40 & PLL, GIL, INT & TROPIC & Peru & 1998-2006 \\
\hline Delord et al., 2005 & 1 & 379 & 0 & DLL & SUBANT & Kerguelen & 2001-2003 \\
\hline Smith and Morgan, 2005 & 2 & 205 & 205 & GIL & SUBARC & NE Pacific & $1995-2001$ \\
\hline Nevins, 2004 & 1 & 785 & 785 & GIL & SUBTRN & California & $1999-2000$ \\
\hline Robertson et al., 2004* & 5 & 643 & 646 & DLL, PLL, TRA & SUBANT, SUBTRS & New Zealand & 2001-2002 \\
\hline Robertson et al., 2003* & 9 & 898 & 1033 & DLL, PLL, TRA & SUBANT, SUBTRS & New Zealand & $2000-2001$ \\
\hline Reid et al., 2004 & 1 & 17 & 0 & DLL & SUBANT & Falklands & 2001-2002 \\
\hline Ryan et al., 2002 & 2 & 0 & 50 & PLL & SUBTRS & South Africa & $1998-2000$ \\
\hline Nel et al., 2002a & 4 & 962 & 241 & DLL & SUBANT & Prince Edward & $1996-2000$ \\
\hline Osterblom et al., 2002 & 1 & 0 & 765 & GIL & SUBARC & Baltic Sea & 1972-1999 \\
\hline Darby and Dawson, 2000 & 1 & 42 & 42 & GIL & SUBANT & New Zealand & 1979-1997 \\
\hline Robertson, $2000^{*}$ & 4 & 161 & 161 & PLL,TRA & SUBANT, SUBTRS & New Zealand & 1998 \\
\hline Robertson and Bell, 2002 & 4 & 150 & 153 & BLL, PLL, TRA & SUBANT, SUBTRS & New Zealand & 1998-1999 \\
\hline Ryan and Box-Hinzen, 1999 & 4 & 388 & 367 & DLL & SUBANT & Prince Edward & 1996-1997 \\
\hline Gandini et al., 1999 & 1 & 31 & 0 & TRA & SUBANT & Argentina & 1995-1997 \\
\hline Simeone et al., 1999 & 1 & 0 & 663 & GIL & SUBANT & Chile & 1991-1996 \\
\hline Thompson et al., 1998 & 2 & 322 & 322 & GIL & SUBARC & NE Pacific & 1994-1994 \\
\hline Gales at al., 1998 & 8 & 407 & 407 & PLL & SUBANT, SUBTRS & Australia & 1988-1995 \\
\hline Barnes et al., 1997 & 1 & 33 & 0 & DLL & SUBTRS & South Africa & 1994 \\
\hline Neves and Olmos, 1997 & 2 & 50 & 50 & PLL & SUBTRS & Brazil & 1994-1995 \\
\hline Langston and Rohwer, 1995 & 2 & 308 & 308 & GIL & SUBTRN & North Pacific & 1990-1991 \\
\hline Stempniewicz, 1994 & 7 & 1149 & 1149 & GIL & SUBARC & Baltic Sea & 1972-76, \\
\hline
\end{tabular}




\begin{tabular}{|c|c|c|c|c|c|c|c|}
\hline & & & & & & & $86-90$ \\
\hline Murray et al., 1993 & 4 & 100 & 105 & PLL & SUBANT, SUBTRS & New Zealand & 1988-1992 \\
\hline Bartle, 1991 & 1 & 35 & 35 & TRA & SUBANT & New Zealand & 1990 \\
\hline Bartle, 1990 & 1 & 16 & 16 & PLL & SUBANT & New Zealand & 1989 \\
\hline Croxal and Prince, 1990 & 1 & 12 & 12 & PLL & SUBTRS & $\begin{array}{l}\text { N Argentina, } \\
\text { Uruguay, Brazil }\end{array}$ & 1984-1986 \\
\hline
\end{tabular}

* Bycatch in subtropical and sub-Antarctic areas of New Zealand was pooled.

1030

1031

1032

1033

1034

1035

1036

1037

1038

1039

1040

1041

1042

1043

1044

1045

1046

1047

1048

1049

1050

1051

1052

1053

1054

1055

1056

1057

1058

1059

1060

1061

1062

1063

1064

1065

1066

1067

1068

1069

1070

1071

1072

1073

1074

1075

1076 
1077

1078

1079

1080

Table 2. Candidate mixed effect models for proportion of males, and proportion of adults in seabird bycatch composition as influenced by region and type of fishery. All models included species as a random effect. Best models are highlighted in bold.

\begin{tabular}{llllll}
\hline Model & df & AICc & $\Delta$ AICc & Deviance & Resid df \\
\hline Sex (y <- proportion of males) & & & & & \\
y $\sim$ Region * Fishery & $\mathbf{5}$ & $\mathbf{- 3 7 . 1 7}$ & $\mathbf{0}$ & $\mathbf{1 4 2 . 2}$ & $\mathbf{7 9}$ \\
Y $\sim$ Region & 3 & -22.37 & 14.8 & 211.98 & 95 \\
y $\sim 1$ & 2 & -18.27 & 18.9 & 183.5 & 80 \\
y $\sim$ Region + Fishery & 4 & 12.17 & 49.34 & 381.34 & 122 \\
y $\sim$ Fishery & 3 & 18.65 & 55.82 & 310.4 & 90 \\
\hline Age (y <- Proportion of adults) & & & & & \\
y $\sim$ Region * Fishery & $\mathbf{5}$ & $\mathbf{4 8 . 4}$ & $\mathbf{0 . 0}$ & $\mathbf{3 5 . 1}$ & $\mathbf{6 8}$ \\
y $\sim$ Region + Fishery & 4 & 55.5 & 7.1 & 44.6 & 69 \\
y Fishery & 3 & 72.1 & 23.7 & 63.3 & 79 \\
Y $\sim$ Region & 3 & 83.3 & 34.9 & 74.8 & 85 \\
y $\sim 1$ & 2 & 109.9 & 61.5 & 103.7 & 112 \\
& & & & &
\end{tabular}

1081 
Table 3. Frequency of bycatch samples per fishery type and region not skewed and skewed toward males (M) or females (F), and toward adults (A) or immatures (I); per fishery type and regions.

\begin{tabular}{lllllllll}
\hline & $\begin{array}{l}\text { Not } \\
\text { skewed }\end{array}$ & M & F & $p\left(\chi^{2}\right)$ & $\begin{array}{l}\text { Not } \\
\text { skewed }\end{array}$ & A & I & $\begin{array}{l}p\left(\chi^{2} \text { Yates }\right): \\
\text { A vs Ia }\end{array}$ \\
\hline Fishery & & & & & & & & \\
Pelagic longline & 18 & 14 & 16 & 0.779 & 5 & 27 & 15 & 0.090 \\
Demersal longline & $\mathbf{9}$ & $\mathbf{1 5}$ & $\mathbf{2}$ & $\mathbf{0 . 0 0 8}$ & 0 & $\mathbf{1 4}$ & $\mathbf{4}$ & $\mathbf{0 . 0 3 4}$ \\
Gillnet & 7 & 6 & 2 & nab & 3 & 8 & 7 & 1.000 \\
Trawl & $\mathbf{5}$ & $\mathbf{1 2}$ & $\mathbf{1}$ & $\mathbf{0 . 0 0 6}$ & 0 & $\mathbf{1 7}$ & $\mathbf{0}$ & $<\mathbf{0 . 0 0 1}$ \\
Longlines combined & 27 & 29 & 18 & 0.249 & 5 & $\mathbf{4 1}$ & $\mathbf{1 9}$ & $\mathbf{0 . 0 0 7}$ \\
Region & & & & & & & & \\
Sub-Antarctic & $\mathbf{1 8}$ & $\mathbf{2 6}$ & $\mathbf{3}$ & $<\mathbf{0 . 0 0 1}$ & 2 & $\mathbf{2 9}$ & $\mathbf{7}$ & $<\mathbf{0 . 0 0 1}$ \\
Sub-Arctic & $\mathbf{8}$ & $\mathbf{8}$ & $\mathbf{1}$ & $\mathbf{0 . 0 5 6}$ & 1 & 11 & 7 & 0.479 \\
Subtropical South & 8 & 5 & 12 & 0.228 & 3 & 10 & 10 & 1.000 \\
Subtropical North & 2 & 2 & 3 & na & 1 & 4 & 2 & na \\
Sub-polar & $\mathbf{2 6}$ & $\mathbf{3 4}$ & $\mathbf{4}$ & $<\mathbf{0 . 0 0 1}$ & 3 & $\mathbf{4 1}$ & $\mathbf{1 5}$ & $<\mathbf{0 . 0 0 1}$ \\
Subtropical & 10 & 7 & 13 & 0.407 & 4 & 14 & 12 & 0.844 \\
\hline
\end{tabular}

a Comparisons were made only between the frequency of adult- and immature-skewed samples since unbalanced age ratios are expected in wild populations; b "na" (not available) refers to frequencies not compared due to small sample sizes. 
Table 4. Candidate mixed effect models for proportion of males, and proportion of adults in seabird bycatch composition as influenced by fishery gear-type consider fisheries in the subpolar region only, which was the region with comparable sample sizes among fisheries. All models included species as a random effect. Best models are highlighted in bold.

\begin{tabular}{lccccc}
\hline Model & $\mathrm{df}$ & $\mathrm{AICc}$ & $\Delta \mathrm{AICc}$ & Deviance & Resid df \\
\hline Sex (y <- proportion of males) & & & & & \\
y Fishery, subpolar only & $\mathbf{4}$ & $\mathbf{- 4 0 . 1}$ & $\mathbf{0 . 0}$ & $\mathbf{7 5 . 9}$ & $\mathbf{5 4}$ \\
y $\sim 1$ & 1 & 12.17 & 5.2 & 381.3 & 122 \\
\hline Age (y <- Proportion of adults) & & & & & \\
y $\sim$ Fishery, subpolar only & $\mathbf{4}$ & $\mathbf{1 4 . 4}$ & $\mathbf{0 . 0}$ & $\mathbf{1 8 8 . 4}$ & $\mathbf{4 7}$ \\
$\mathrm{y} \sim 1$ & 1 & 95.6 & 81.2 & 1033.9 & 114 \\
\hline
\end{tabular}


1206

1207

1208

1209

1210

1211

1212

1213

1214

1215

1216

1217

1218

1219

1220

1221

1222

1223

1224

1225

1226

1227

1228

1229

1230

1231

\section{FIGURES}

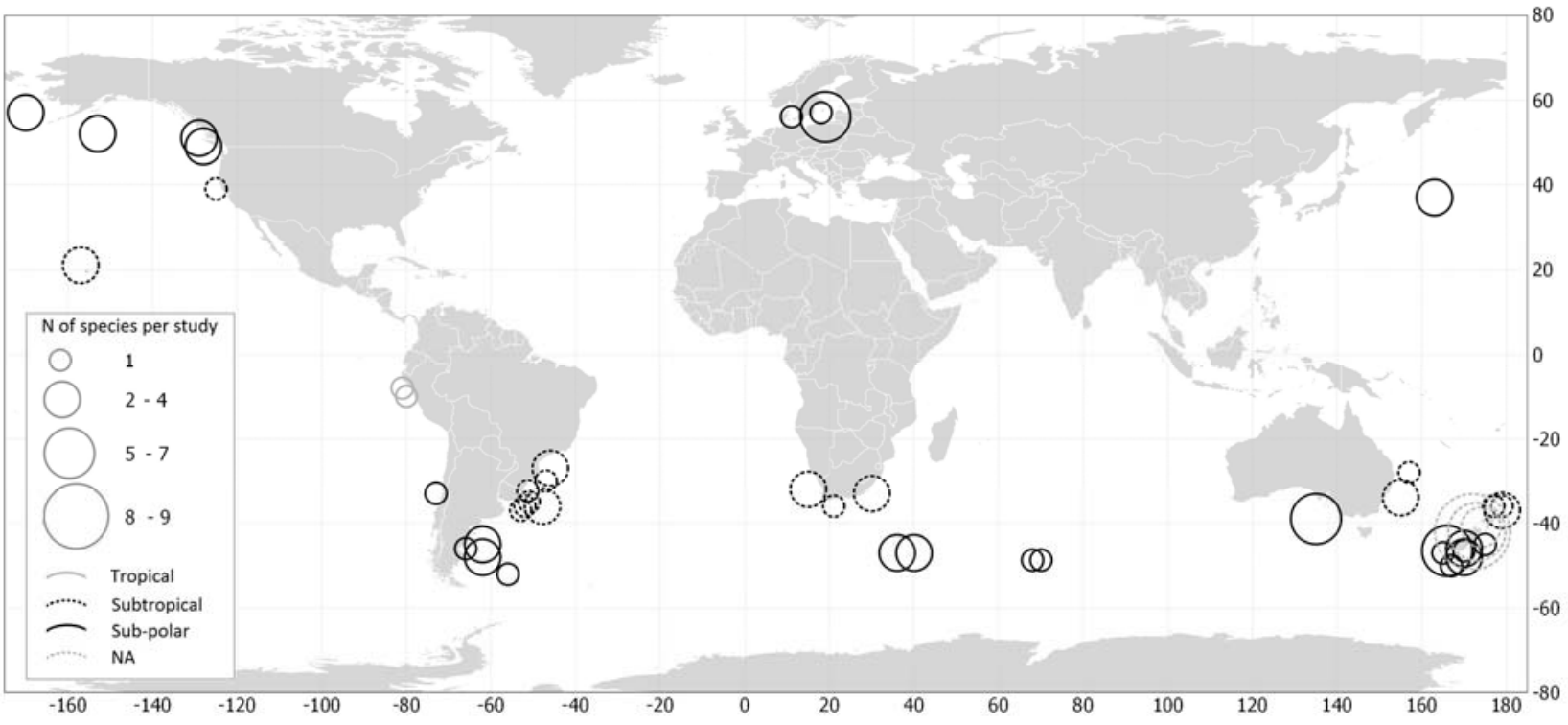

Figure 1. (Two columns fitting) 

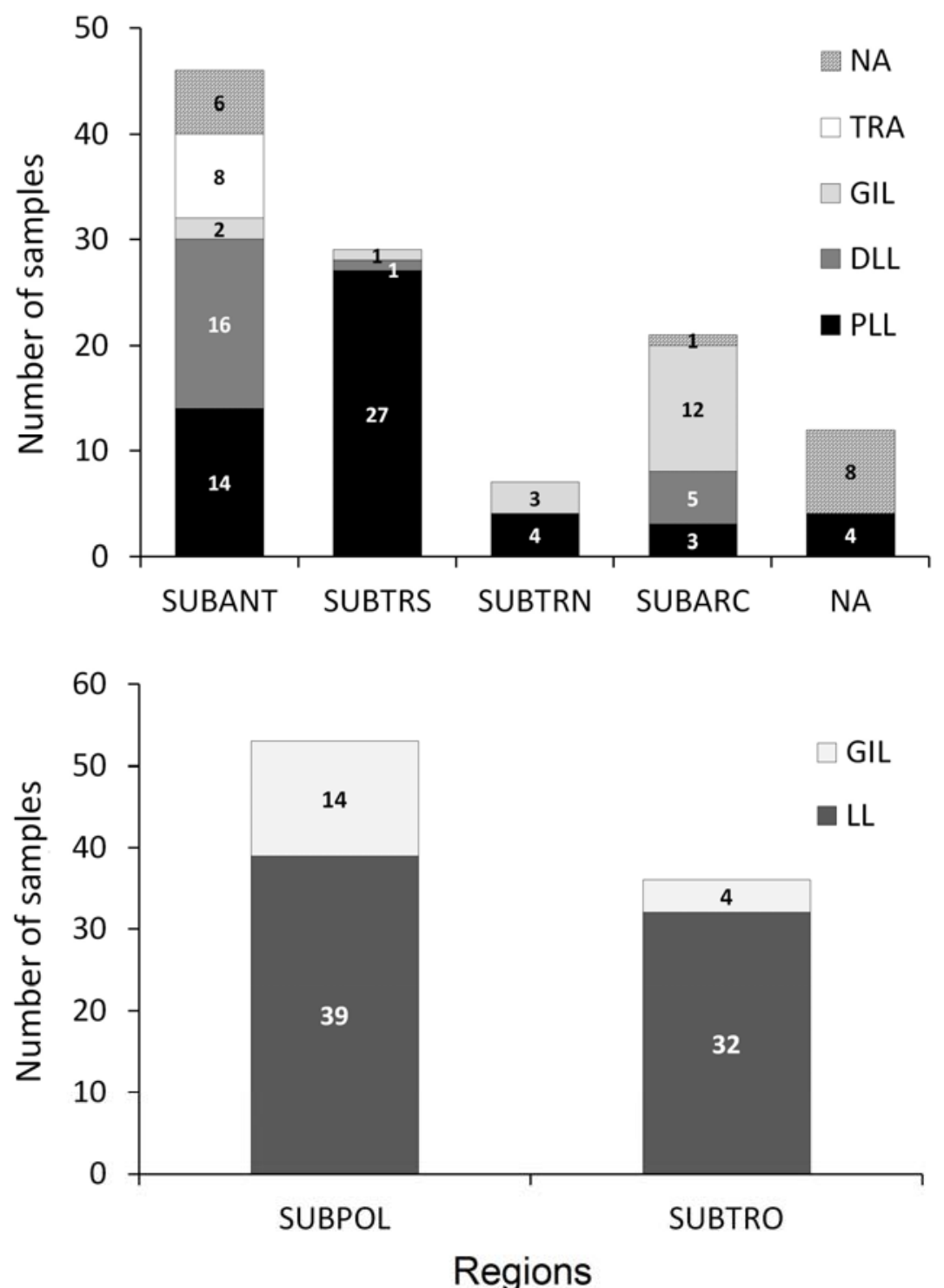

1232

1233

1234

Figure 2. (Single column fitting) 
Males Females

$\begin{array}{llllll}0 \% & 20 \% & 40 \% & 60 \% & 80 \% & 100 \%\end{array}$

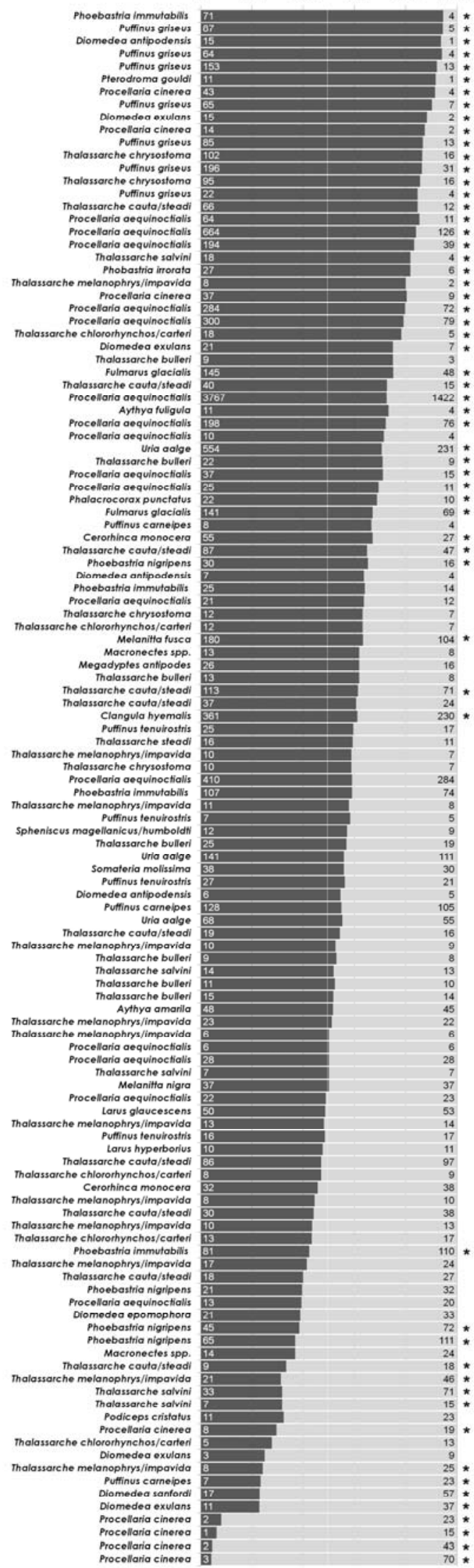

Adults Immature

$\begin{array}{llllll}0 \% & 20 \% & 40 \% & 60 \% & 80 \% & 100 \%\end{array}$

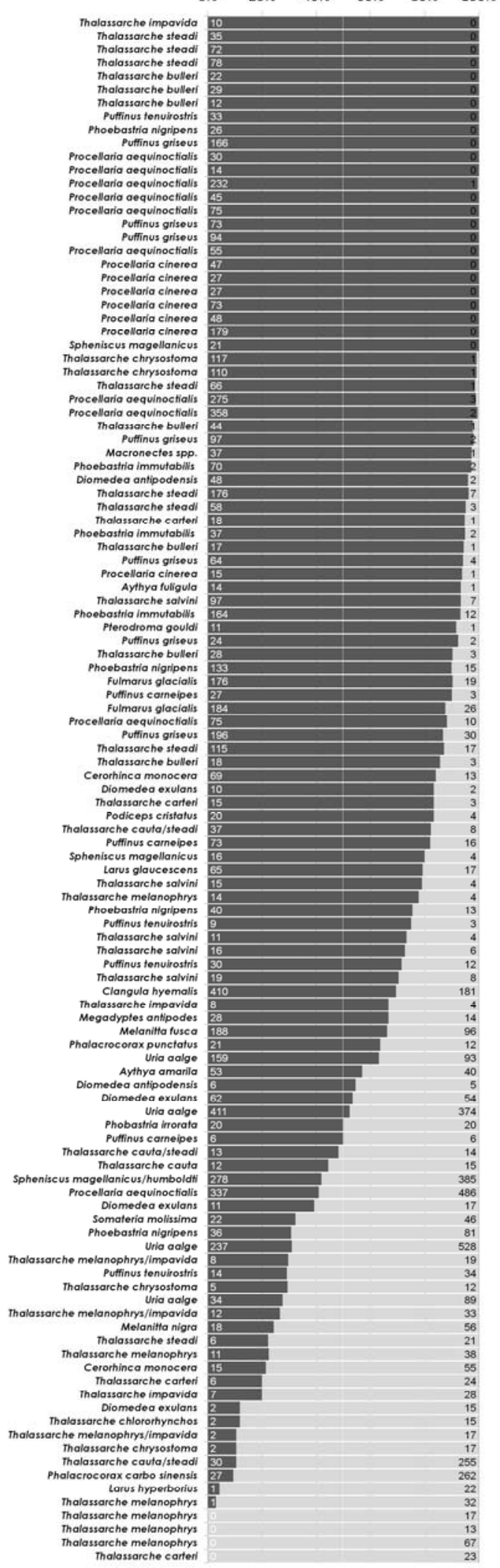


80

40
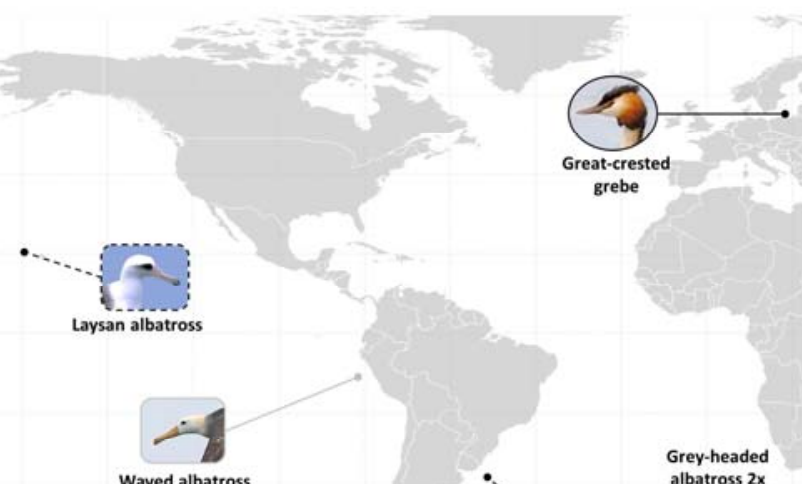

1239

1240

1241

1242

1243

1244

1245

1246

1247

1248

1249

1250

1251

1252

1253

1254

1255

1256

1257

1258

1259

\section{Figure 4. (Two columns fitting)}

$-40$

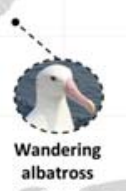

Grey-headed
albatross $2 \mathrm{x}$

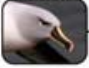

$-80$

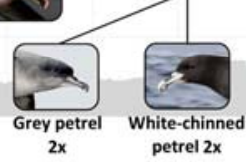

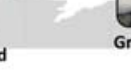

(2)

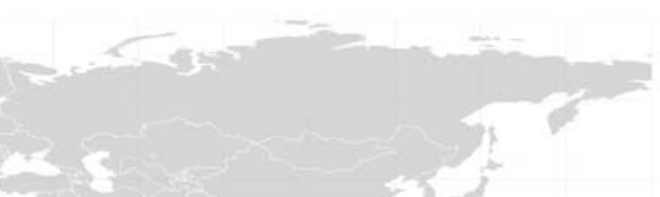

Grey petrel $4 x$

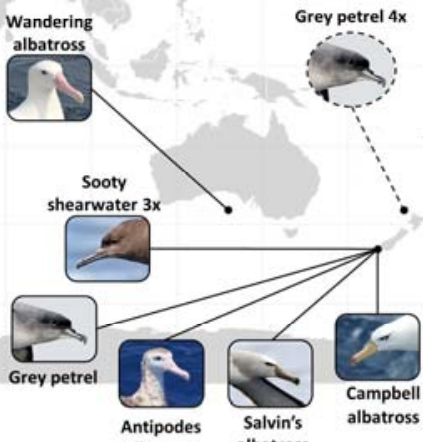

albatross 

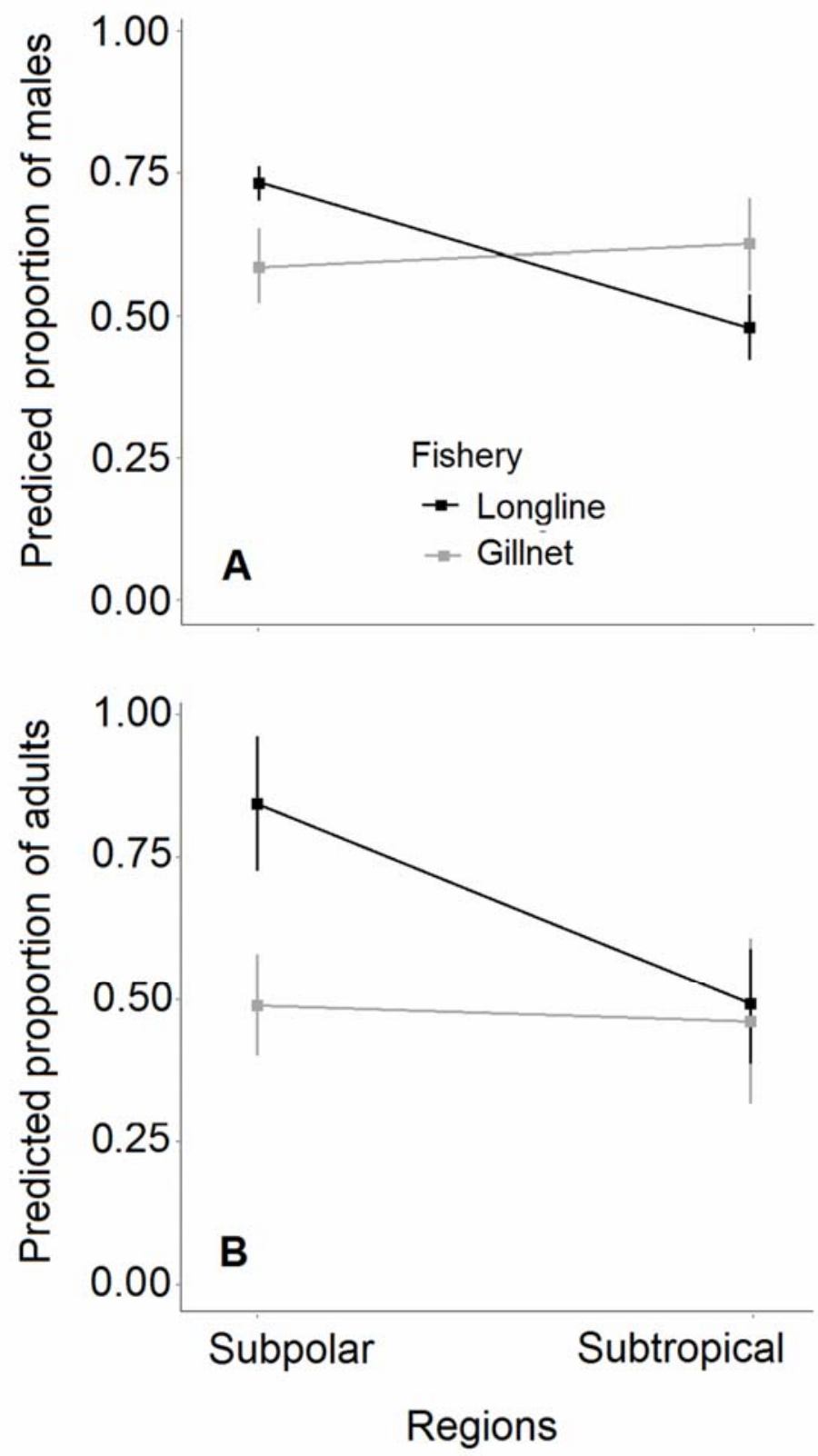

Figure 5. (Single column fit) 

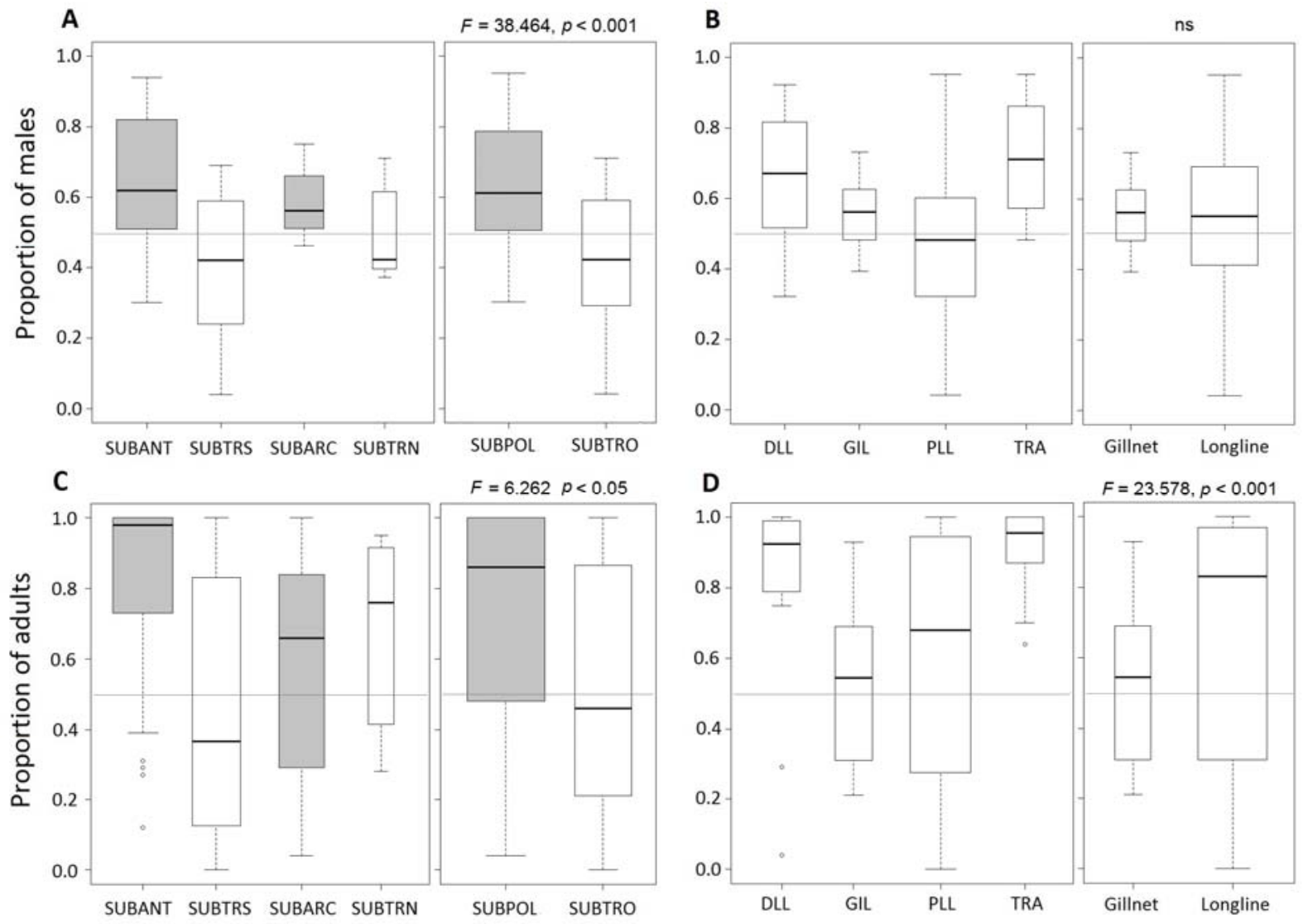

Regions

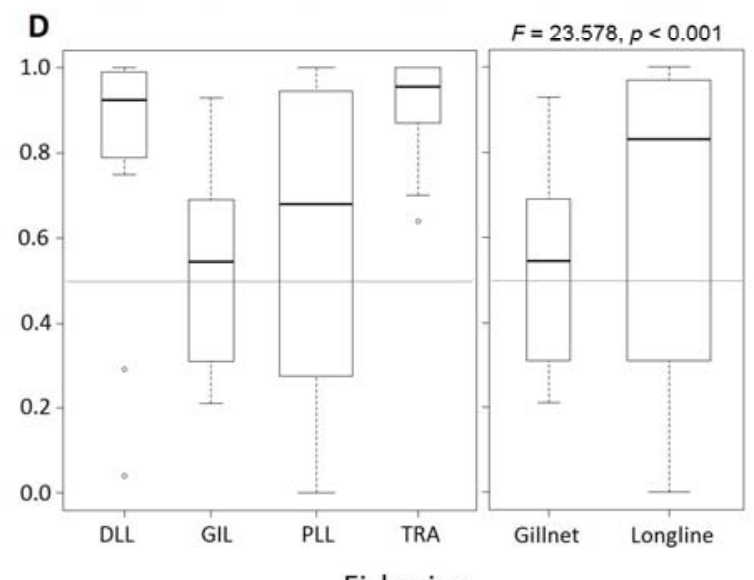

Fisheries

Figure 6. (1.5 column fitting) 

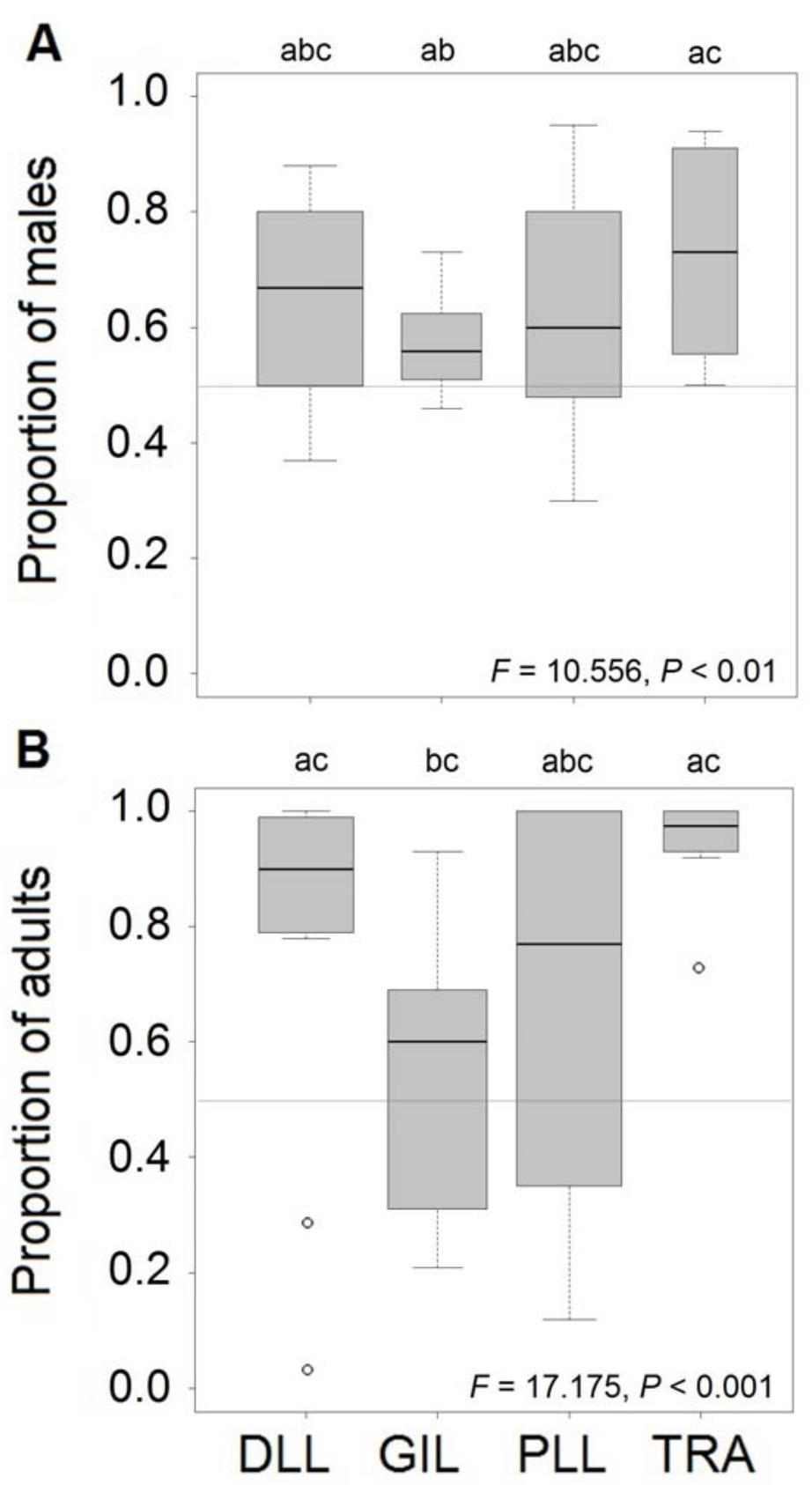

Figure 7. (Single column) 

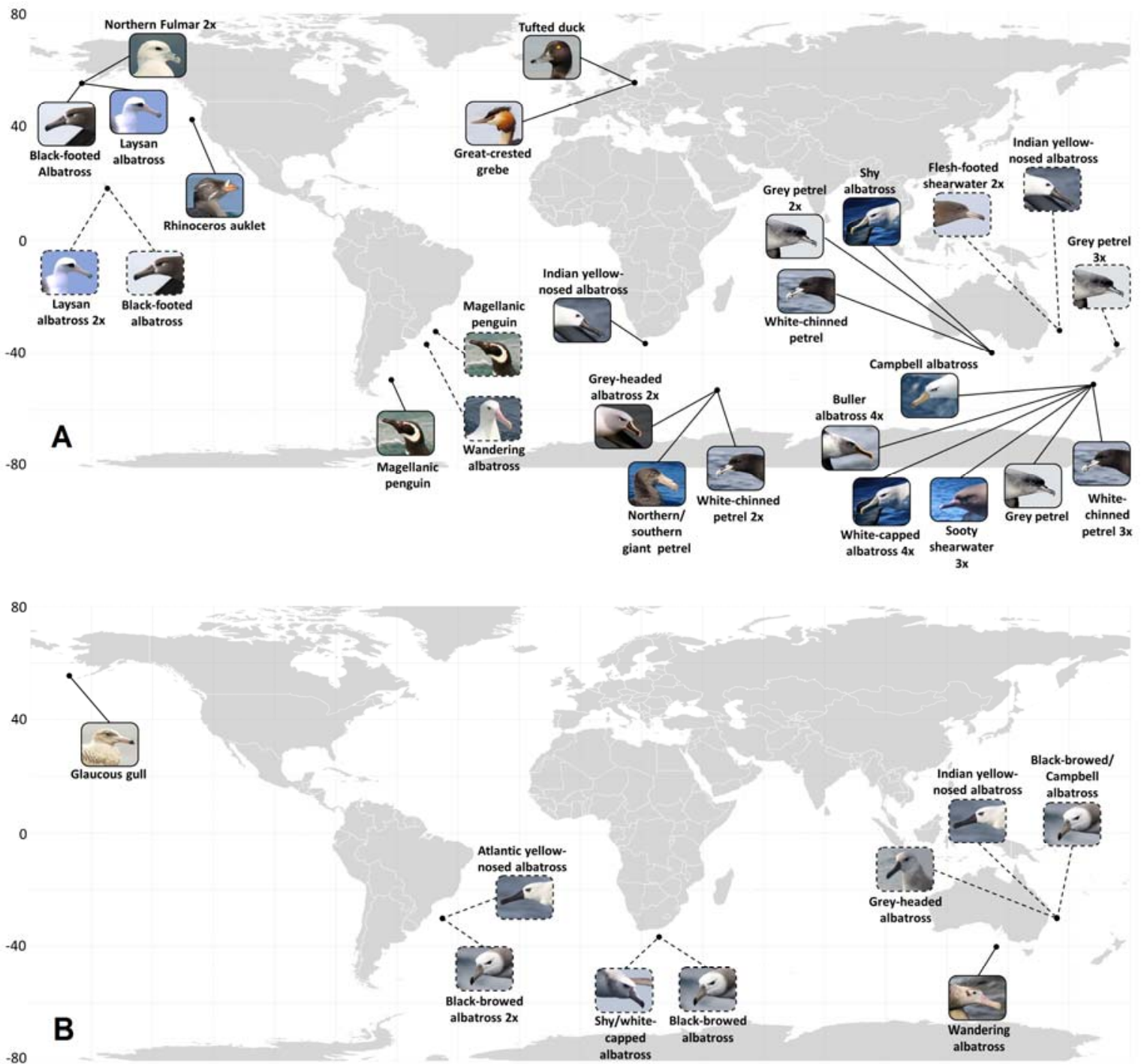

Figure 8. (Two columns fitting) 


\section{FIGURE LEGENDS}

Figure 1. Spatial distribution of seabird bycatch studies with data on sex and age composition. The size of the circles indicates the number of species per study. Black solid and dotted circles indicate subpolar and subtropical regions, respectively. Light grey solid circles show studies in the tropics (Peru), and light grey dotted circles correspond to studies from New Zealand without detailed information on region (NA), which were therefore excluded from the analysis of regional effects. (Two columns fitting)

Figure 2. Number of bycatch samples by main fishery type and regions, reflecting $(A)$ the original data, and (B) fisheries categories collapsed for the purposes of modelling. Abbreviations: SUBANT, sub-Antarctic; SUBARC, sub-Arctic; SUBTRS, subtropical southern; SUBTRN, subtropical northern; SUBPOL, subpolar; SUBTRO, subtropical; PLL, pelagic longline; DLL, demersal longline; GIL, gillnet; TRA, trawl; LL, longline; NA, detailed data per fishery type or region was not available. (Single column fitting)

Figure 3. Sex (A) and age ratios (B) of seabird species reported as bycatch in global fisheries. The number of individuals in each sample is shown inside the bars, and asterisks indicate sex compositions that deviated statistically from the expected sex ratio of 1:1 $\left(\chi^{2}\right.$ Yates, $\left.\mathrm{P}<0.05\right)$. Deviation from a 1:1 ratio age ratios were not tested because equal proportions of adults and immatures are not expected in wild populations. (Two columns fitting)

Figure 4. Geographical distribution of the highly sex-biased bycatch samples $(\geq 80 \%$ of one sex). Squared figures refer to male and circled figures refer to female-biased samples. Black solid, black dotted and grey lines denote bycatch events in subpolar, subtropical and tropical regions respectively. Highly sex-biased samples from studies that subtropical and sub-Antarctic areas of New Zealand were pooled are not shown. The numbers follow common names indicate the number of sex-biased samples for that taxon in the given location. (Two columns fitting)

Figure 5. Interaction effect of region (subpolar vs subtropical) and fishery type (longline [demersal and pelagic combined] vs gillnet) on the proportion of males (A) and adults (B) in seabird bycatch. (Single column fit)

Figure 6. Proportion of males (top) and of adults (bottom) in seabird bycatch samples by region (left) and fishery type (right). Box plots show the median and the $25^{\text {th }}$ and $75^{\text {th }}$ percentiles, whiskers indicate values within 1.5 times of the interquartile range, circles 
represent outliers, and box plot width varies with the sample size, and the horizontal grey line indicates the 0.5 mark. Abbreviations: SUBANT, sub-Antarctic; SUBARC, sub-Arctic; SUBTRS, subtropical southern; SUBTRN, subtropical northern; SUBPOL, subpolar; SUBTRO, subtropical; PLL, pelagic longline; DLL, demersal longline; GIL, gillnet; TRA, trawl. Grey boxes in A and C indicate subpolar regions. F-statistic and P-value from ANOVA comparing the effect of region (subtropical vs subpolar) and fishery type (longline [demersal and pelagic combined] vs gillnet) are shown inside the graph area (Two columns fitting)

Figure 7. Proportion of males (A) and of adults (B) in seabird bycatch samples compared among the four major gear types using only data from subpolar regions. Box plots show the median and the $25^{\text {th }}$ and $75^{\text {th }}$ percentiles, whiskers indicate values within 1.5 times of the interquartile range, circles represent outliers, box plot width varies with the sample size, and the horizontal grey line indicates the 0.5 mark. Abbreviations: PLL, pelagic longline; DLL, demersal longline; GIL, gillnet; TRA, trawl. F-statistic and P-value from ANOVA comparing the effect of fishery type are shown inside the graph area. Box-plots not sharing the same lower case letters are statistically distinct $(P<0.05)$ according to Tukey post-hoc test. (Single column)

Figure 8. Geographical distribution of bycatch samples highly skewed towards adult (A) or towards immature (B) ( $\geq 80 \%$ of one age class). Solid and dotted lines denote bycatch events in subpolar and subtropical regions respectively. The numbers following common names indicate the number of highly age-biased samples for that taxon in the given location. (Two columns fitting) 
Appendix A. List of the species included in this study.

\begin{tabular}{|c|c|c|c|}
\hline Family & Common name & Specie & IUCN $^{*}$ \\
\hline \multirow[t]{16}{*}{ Albatrosses (Diomedeidae) } & Wandering albatross & Diomedea exulans & $\mathrm{VU}$ \\
\hline & Antipodean albatross & Diomedea antipodensis & $\mathrm{VU}$ \\
\hline & Northern royal albatross & Diomedea sanfordi & EN \\
\hline & Southern royal albatross & Diomedea epomophora & VU \\
\hline & Black-browed albatross & Thalassarche melanophris & NT \\
\hline & Campbell albatross & Thalassarche impavida & VU \\
\hline & White-capped albatross & Thalassarche steadi & NT \\
\hline & Shy albatross & Thalassarche cauta & NT \\
\hline & Salvin's albatross & Thalassarche salvini & VU \\
\hline & Grey-headed albatross & Thalassarche chrysostoma & EN \\
\hline & Buller's albatross & Thalassarche bulleri & NT \\
\hline & Atlantic yellow-nosed albatross & Thalassarche chlororhynchos & EN \\
\hline & Indian yellow-nosed albatross & Thalassarche carteri & EN \\
\hline & Laysan albatross & Phoebastria immutabilis & NT \\
\hline & Black-footed albatross & Phoebastria nigripes & NT \\
\hline & Waved albatross & Phoebastria irrorata & CR \\
\hline \multirow[t]{9}{*}{ Petrels (Procellaridae) } & Southern giant petrel & Macronectes giganteus & LC \\
\hline & Northern giant petrel & Macronectes halli & LC \\
\hline & Northern fulmar & Fulmarus glacialis & LC \\
\hline & Flesh-footed shearwater & Puffinus carneipes & LC \\
\hline & White-chinned petrel & Procellaria aequinoctialis & VU \\
\hline & Short-tailed shearwater & Puffinus tenuirostris & LC \\
\hline & Sooty shearwater & Puffinus griseus & NT \\
\hline & Grey petrel & Procellaria cinerea & LC \\
\hline & Grey-faced petrel & Pterodroma gouldi & LC \\
\hline \multirow[t]{6}{*}{ Sea ducks (Merginae) } & Tufted duck & Aythya fuligula & LC \\
\hline & Greater scaup & Aythya marila & LC \\
\hline & Long-tailed duck & Clangula hyemalis & VU \\
\hline & Velvet scoter & Melanitta fusca & EN \\
\hline & Common scoter & Melanitta nigra & LC \\
\hline & Common eider & Somateria mollissima & LC \\
\hline \multirow[t]{3}{*}{ Penguins (Spheniscidae) } & Yellow-eyed penguin & Megadyptes antipodes & EN \\
\hline & Magellanic penguin & Spheniscus magellanicus & NT \\
\hline & Humboldt penguin & Spheniscus humboldti & VU \\
\hline \multirow[t]{2}{*}{ Auks (Alcidae) } & Common guillemot & Uria aalge & LC \\
\hline & Rhinoceros auklet & Cerorhinca monocerata & LC \\
\hline \multirow[t]{2}{*}{ Gulls (Laridae) } & Glaucous-winged gull & Larus glaucescens & LC \\
\hline & Glaucous gull & Larus hyperboreus & LC \\
\hline \multirow[t]{2}{*}{ Cormorants (Phalacrocoracidae) } & Great cormorant & Phalacrocorax carbo & LC \\
\hline & Spotted shag & Phalacrocorax punctatus & LC \\
\hline Grebes (Podicipodidae) & Great crested grebe & Podiceps cristatus & LC \\
\hline
\end{tabular}

* IUCN Status: LC, Least concern; NT, Near threat; VU, Vulnerable; EN, Endangered; CR, Critically endangered. 
Apendix B. Detailed information of each bycatch report comprised for the present study, including specie, number of birds sexed (N sexed), number of males (M) and females (F), proportion of males (P_M), number of birds aged (N aged), number of adults (A) and immature (I), proportion of adults (P_A), fishery type (Fishery), location, region, period of study and reference. Abbreviations: SUBANT, sub-Antarctic; SUBARC, sub-Arctic; SUBTRS, subtropical southern; SUBTRN, subtropical northern; SUBPOL, subpolar; SUBTRO, subtropical; TROPIC, tropical; PLL, pelagic longline; DLL, demersal longline; GIL, gillnet; TRA, trawl; POU, pound net; INT, intentional catch.

\begin{tabular}{|c|c|c|c|c|c|c|c|c|c|c|c|c|c|c|}
\hline Specie $^{1}$ & $\begin{array}{l}\mathbf{N} \\
\text { sexed }\end{array}$ & $M$ & $\mathbf{F}$ & P_M & $\begin{array}{l}p \chi^{2} \\
\text { Yates }\end{array}$ & $\begin{array}{l}\mathbf{N} \\
\text { aged }\end{array}$ & A & I & P_A & Fishery & Area & Region & Period of study & Reference \\
\hline DIEXU & 12 & 3 & 9 & 0.25 & ns & 12 & 10 & 2 & 0.83 & $\mathrm{PLL}$ & SW Atlantic & SUBTRS & $1984-1986$ & Croxall \& Prince (1990) \\
\hline DIEXU & 28 & 21 & 7 & 0.76 & $<0.05$ & 28 & 11 & 17 & 0.39 & PLL & Australia & SUBANT & 1988-1995 & Gales at al. (1998) \\
\hline DIEXU & 17 & 15 & 2 & 0.86 & $<0.005$ & 17 & 2 & 15 & 0.12 & PLL & Australia & SUBANT & 1988-1995 & Gales at al. (1998) \\
\hline DIEXU & 48 & 11 & 27 & 0.23 & $<0.05$ & 116 & 62 & 54 & 0.53 & PLL & Uruguay & SUBTRS & 1999-2012 & Jiménez et al. (2015a) \\
\hline DIANT & 11 & 6 & 5 & 0.55 & ns & na & na & na & na & PLL & New Zealand & SUBTRS & 1997 & Burg (2008) \\
\hline DIANT & 11 & 7 & 4 & 0.63 & ns & 11 & 6 & 5 & 0.54 & PLL & New Zealand & SUBTRS, SUBANT & 1988-1992 & Murray et al. (1993) \\
\hline DIANT & 16 & 15 & 1 & 0.94 & 0.001 & na & na & na & na & PLL & New Zealand & SUBANT & 1997 & Burg (2008) \\
\hline DIANT & 50 & 24 & 26 & 0.48 & ns & 50 & 48 & 2 & 0.96 & PLL & New Zealand & SUBTRS, SUBANT & 1998 & Robertson (2000) \\
\hline DISAN & 74 & 17 & 57 & 0.23 & $<0.01$ & na & na & na & na & PLL & Uruguay & SUBTRS & 2004-2012 & Jiménez et al. (2016) \\
\hline DIEPO & 54 & 21 & 33 & 0.39 & ns & na & na & na & na & PLL & Uruguay & SUBTRS & 2004-2012 & Jiménez et al. (2016) \\
\hline THMEL & 19 & 10 & 9 & 0.53 & ns & na & na & na & na & DLL & Argentina & SUBANT & $200-2001$ & Gandini and Frere (2006) \\
\hline THMEL & 33 & 8 & 25 & 0.24 & $<0.001$ & 33 & 1 & 32 & 0.03 & PLL & Brazil & SUBTRS & 1994-1995 & Neves and Olmos (1998) \\
\hline THMEL & 17 & 10 & 7 & 0.59 & ns & 17 & 0 & 17 & 0.00 & DLL & Falklands & SUBANT & 2001-2002 & Reid et al. (2004) \\
\hline THMEL & 18 & 8 & 10 & 0.44 & ns & 18 & 14 & 4 & 0.78 & DLL & Argentina & SUBANT & 2005 & Seco-Pon et al. (2007) \\
\hline THMEL & 41 & 17 & 24 & 0.41 & ns & 49 & 11 & 38 & 0.22 & PLL & South Africa & SUBTRS & $1998-2005$ & Petersen et al. (2010) \\
\hline
\end{tabular}




\begin{tabular}{|c|c|c|c|c|c|c|c|c|c|c|c|c|c|c|}
\hline THIMP & 12 & 6 & 6 & 0.50 & ns & 12 & 8 & 4 & 0.67 & PLL & New Zealand & SUBTRS, SUBANT & 1998 & Robertson (2000) \\
\hline THIMP & 10 & 8 & 2 & 0.80 & ns & 10 & 10 & 0 & 1.00 & PLL & New Zealand & SUBANT & 2006-2007 & Thompson (2010a) \\
\hline THIMP & 23 & 10 & 13 & 0.43 & ns & 25 & 7 & 28 & 0.28 & PLL & New Zeland & SUBTRS & 1988-1992 & Murray et al. (1993) \\
\hline THMEL/THIMP & 19 & 11 & 8 & 0.60 & ns & 19 & 2 & 17 & 0.13 & PLL & Australia & SUBTRS & 1988-1995 & Gales at al. (1998) \\
\hline THMEL/THIMP & 45 & 23 & 22 & 0.51 & ns & 45 & 12 & 33 & 0.27 & PLL & Australia & SUBANT & 1988-1995 & Gales at al. (1998) \\
\hline THMEL/THIMP & 27 & 13 & 14 & 0.47 & ns & 27 & 8 & 19 & 0.31 & PLL & Australia & SUBANT & 1988-1995 & Gales at al. (1998) \\
\hline THMEL & na & na & na & na & na & 13 & 0 & 13 & 0.00 & PLL & South Africa & SUBTRS & $1998-2000$ & Ryan et al. (2002) \\
\hline THMEL & 67 & 21 & 46 & 0.31 & $<0.005$ & 67 & 0 & 67 & 0.00 & PLL & Brazil & SUBTRS & $2006-2008$ & Roma (2009) \\
\hline THCHR & 118 & 102 & 16 & 0.86 & $<0.0001$ & 118 & 117 & 1 & 0.99 & DLL & Prince Edward & SUBANT & $1996-2000$ & Nel et al. (2002a) \\
\hline THCHR & 111 & 95 & 16 & 0.86 & $<0.0001$ & 111 & 110 & 1 & 0.99 & DLL & Prince Edward & SUBANT & 1996-1997 & $\begin{array}{l}\text { Ryan and Box-Hinzen } \\
\text { (1999) }\end{array}$ \\
\hline THCHR & 19 & 12 & 7 & 0.64 & ns & 19 & 2 & 17 & 0.09 & PLL & Australia & SUBTRS & $1988-1995$ & Gales at al. (1998) \\
\hline THCHR & 17 & 10 & 7 & 0.60 & ns & 17 & 5 & 12 & 0.29 & PLL & Australia & SUBANT & $1988-1995$ & Gales at al. (1998) \\
\hline THCAU/THSTE & 183 & 86 & 97 & 0.47 & ns & 285 & 30 & 255 & 0.11 & PLL & South Africa & SUBTRS & $1998-2005$ & Petersen et al. (2010) \\
\hline THCAU/THSTE & 45 & 18 & 27 & 0.41 & ns & 45 & 37 & 8 & 0.83 & PLL & Australia & SUBANT & 1988-1995 & Gales at al. (1998) \\
\hline THCAU/THSTE & 27 & 9 & 18 & 0.32 & ns & 27 & 13 & 14 & 0.48 & PLL & Australia & SUBANT & 1988-1995 & Gales at al. (1998) \\
\hline THSTE & 27 & 16 & 11 & 0.59 & ns & 27 & 6 & 21 & 0.22 & PLL & Uruguay & SUBANT & $2008-2011$ & Jimenez et al. (2015b) \\
\hline THSTE & 35 & 19 & 16 & 0.54 & ns & 35 & 35 & 0 & 1.00 & TRA & New Zeland & SUBANT & 1990 & Bartle (1991) \\
\hline THSTE & 55 & 40 & 15 & 0.73 & $<0.005$ & 67 & 66 & 1 & 0.99 & TRA & New Zeland & SUBTRS, SUBANT & 2008-2009 & Thompson (2010b) \\
\hline THSTE & 68 & 30 & 38 & 0.44 & ns & 72 & 72 & 0 & 1.00 & PLL, TRA & New Zeland & SUBANT & 2006-2007 & Thompson (2010a) \\
\hline THSTE & 184 & 113 & 71 & 0.61 & $<0.005$ & 183 & 176 & 7 & 0.96 & TRA & New Zealand & SUBTRS, SUBANT & $2000-2001$ & Robertson et al. (2003) \\
\hline
\end{tabular}




\begin{tabular}{|c|c|c|c|c|c|c|c|c|c|c|c|c|c|c|}
\hline THSTE & 134 & 87 & 47 & 0.65 & $<0.001$ & 132 & 115 & 17 & 0.87 & TRA & New Zealand & SUBTRS, SUBANT & 2001-2002 & Robertson et al. (2004) \\
\hline THSTE & 61 & 37 & 24 & 0.61 & ns & 61 & 58 & 3 & 0.95 & TRA & New Zealand & SUBANT & 1998-1999 & Robertson and Bell (2002) \\
\hline THSTE & 78 & 66 & 12 & 0.85 & $<0.0001$ & 78 & 78 & 0 & 1.00 & TRA & New Zealand & SUBANT & $2005-2006$ & Thompson et al. (2009) \\
\hline THCAU & na & na & na & na & na & 37 & 12 & 15 & 0.32 & PLL & South Africa & SUBTRS & $1998-2000$ & Ryan et al. (2002) \\
\hline THSAL & 22 & 18 & 4 & 0.82 & $<0.001$ & 22 & 15 & 4 & 0.68 & PLL & New Zealand & SUBANT & 2006-2007 & Thompson (2010a) \\
\hline THSAL & 14 & 7 & 7 & 0.50 & ns & 15 & 11 & 4 & 0.73 & TRA & New Zealand & SUBANT & 1998-1999 & Robertson and Bell (2002) \\
\hline THSAL & 27 & 14 & 13 & 0.52 & ns & 27 & 19 & 8 & 0.70 & TRA & New Zealand & SUBTRS, SUBANT & 2008-2009 & Thompson (2010b) \\
\hline THSAL & 104 & 33 & 71 & 0.32 & $<0.001$ & 104 & 97 & 7 & 0.93 & DLL & New Zealand & SUBTRS, SUBANT & $2000-2001$ & Robertson et al. (2003) \\
\hline THSAL & 22 & 7 & 15 & 0.32 & ns & 22 & 16 & 6 & 0.73 & PLL,TRA & New Zealand & SUBTRS, SUBANT & 2001-2002 & Robertson et al. (2004) \\
\hline THCHL & 17 & 5 & 13 & 0.29 & ns & 17 & 2 & 15 & 0.12 & PLL & Brazil & SUBTRS & 1994-1995 & Neves and Olmos (1997) \\
\hline THCAR & 23 & 18 & 5 & 0.78 & ns & 23 & 0 & 23 & 0.00 & DLL & Prince Edward & SUBANT & 1996-1997 & $\begin{array}{l}\text { Ryan and Box-Hinzen } \\
\text { (1999) }\end{array}$ \\
\hline THCAR & 17 & 8 & 9 & 0.45 & ns & 18 & 15 & 3 & 0.83 & PLL & South Africa & SUBTRS & 1998-2005 & Petersen et al. (2010) \\
\hline THCAR & 30 & 13 & 17 & 0.44 & ns & 30 & 6 & 24 & 0.20 & PLL & Australia & SUBTRS & 1988-1995 & Gales at al. (1998) \\
\hline THCAR & 19 & 12 & 7 & 0.62 & ns & 19 & 18 & 1 & 0.94 & PLL & Australia & SUBTRS & 1988-1995 & Gales at al. (1998) \\
\hline THBUL & 21 & 11 & 10 & 0.52 & ns & 22 & 22 & 0 & 1.00 & PLL & New Zealand & SUBANT & 1988-1992 & Murray et al. (1993) \\
\hline THBUL & 29 & 15 & 14 & 0.52 & ns & 29 & 29 & 0 & 1.00 & PLL,TRA & New Zealand & SUBANT & 1998-1999 & Robertson and Bell (2002) \\
\hline THBUL & 44 & 25 & 19 & 0.57 & ns & 45 & 44 & 1 & 0.98 & PLL & New Zealand & SUBANT & 2006-2007 & Thompson (2010a) \\
\hline THBUL & 31 & 22 & 9 & 0.71 & $<0.05$ & 31 & 28 & 3 & 0.90 & PLL,TRA & New Zealand & SUBTRS, SUBANT & 2008-2009 & Thompson (2010b) \\
\hline THBUL & 17 & 9 & 8 & 0.53 & ns & 18 & 17 & 1 & 0.94 & PLL,TRA & New Zealand & SUBTRS, SUBANT & $2000-2001$ & Robertson et al. (2003) \\
\hline THBUL & 21 & 13 & 8 & 0.62 & ns & 21 & 18 & 3 & 0.86 & PLL,TRA & New Zealand & SUBTRS, SUBANT & 2001-2002 & Robertson et al. (2004) \\
\hline
\end{tabular}




\begin{tabular}{|c|c|c|c|c|c|c|c|c|c|c|c|c|c|c|}
\hline THBUL & 12 & 9 & 3 & 0.75 & ns & 12 & 12 & 0 & 1.00 & na & New Zealand & SUBANT & 2005-2006 & Thompson et al. (2009) \\
\hline PHIMM & 191 & 81 & 110 & 0.42 & $<0.05$ & 191 & 54 & 137 & 0.28 & GIL & North Pacific & SUBTRN & 1990-1991 & $\begin{array}{l}\text { Langston and Rohwer } \\
\text { (1995) }\end{array}$ \\
\hline PHIMM & 39 & 25 & 14 & 0.64 & ns & 39 & 37 & 2 & 0.95 & PLL & Hawaii & SUBTRN & 2013 & Beck et al. (2013) \\
\hline PHIMM & 181 & 107 & 74 & 0.59 & $<0.05$ & 176 & 164 & 12 & 0.93 & PLL & Hawaii & SUBTRN & $2007-2012$ & Beck et al. (2013) \\
\hline PHIMM & 75 & 71 & 4 & 0.95 & $<0.0001$ & 72 & 70 & 2 & 0.97 & PLL & Alaska & SUBARC & $2007-2012$ & Beck et al. (2013) \\
\hline PHNIG & 117 & 45 & 72 & 0.39 & $<0.05$ & 117 & 36 & 81 & 0.31 & GIL & North Pacific & SUBTRN & 1990-1991 & $\begin{array}{l}\text { Langston and Rohwer } \\
\text { (1995) }\end{array}$ \\
\hline PHNIG & 53 & 21 & 32 & 0.40 & ns & 53 & 40 & 13 & 0.76 & PLL & Hawaii & SUBTRN & 2013 & Beck et al. (2013) \\
\hline PHNIG & 176 & 65 & 111 & 0.37 & $<0.001$ & 148 & 133 & 15 & 0.90 & PLL & Hawaii & SUBTRN & 2007-2012 & Beck et al. (2013) \\
\hline PHNIG & 46 & 30 & 16 & 0.65 & 0.0553 & 26 & 26 & 0 & 1.00 & PLL & Alaska & SUBARC & 2007-2012 & Beck et al. (2013) \\
\hline PHIRR & 33 & 27 & 6 & 0.82 & $<0.01$ & na & na & na & na & PLL,GIL,INT & Peru & TROPIC & 2005 & Awkerman et al. (2006) \\
\hline PHIRR & na & na & na & na & na & 40 & 20 & 20 & 0.50 & PLL,GIL,INT & Peru & TROPIC & 1998-2006 & $\begin{array}{l}\text { Jiménez- Uzcátegui et al. } \\
\text { (2006) }\end{array}$ \\
\hline MAGIG & 21 & 13 & 8 & 0.62 & ns & na & na & na & na & DLL & Prince Edward & SUBANT & 1996-1997 & $\begin{array}{l}\text { Ryan and Box-Hinzen } \\
\text { (1999) }\end{array}$ \\
\hline MAGIG/MAHAL & 38 & 14 & 24 & 0.37 & ns & 38 & 37 & 1 & 0.97 & DLL & Prince Edward & SUBANT & $1996-2000$ & Nel et al. (2002a) \\
\hline FUGLA & 193 & 145 & 48 & 0.75 & $<0.0001$ & 195 & 176 & 19 & 0.90 & DLL & Alaska & SUBARC & 2005 & Phillips et al. (2010) \\
\hline FUGLA & 210 & 141 & 69 & 0.67 & $<0.0001$ & 210 & 184 & 26 & 0.88 & DLL & Alaska & SUBARC & 2013 & Beck et al. (2013) \\
\hline ARCAR & 233 & 128 & 105 & 0.55 & ns & 89 & 73 & 16 & 0.82 & PLL & Australia & SUBTRS & 2001-2006 & Trebilco et al. (2011) \\
\hline ARCAR & 30 & 7 & 23 & 0.24 & $<0.01$ & 30 & 27 & 3 & 0.91 & PLL & Australia & SUBTRS & 1988-1995 & Gales at al. (1998) \\
\hline ARCAR & 12 & 8 & 4 & 0.69 & ns & 12 & 6 & 6 & 0.46 & PLL & Australia & SUBTRS & 1988-1995 & Gales at al. (1998) \\
\hline ARTEN & 48 & 27 & 21 & 0.56 & ns & 48 & 14 & 34 & 0.29 & DLL & Alaska & SUBANT & 2005 & Phillips et al. (2010) \\
\hline
\end{tabular}




\begin{tabular}{|c|c|c|c|c|c|c|c|c|c|c|c|c|c|c|}
\hline ARTEN & 12 & 7 & 5 & 0.58 & ns & 12 & 9 & 3 & 0.75 & DLL & New Zealand & SUBTRS, SUBANT & $2000-2001$ & Robertson et al. (2003) \\
\hline ARTEN & 42 & 25 & 17 & 0.60 & ns & 42 & 30 & 12 & 0.71 & PLL & Alaska & SUBANT & 2013 & Beck et al. (2013) \\
\hline ARTEN & 33 & 16 & 17 & 0.48 & ns & 33 & 33 & 0 & 1.00 & TRA & New Zealand & SUBTRS, SUBANT & $2000-2001$ & Robertson et al. (2003) \\
\hline ARGRI & 68 & 64 & 4 & 0.94 & $<0.0001$ & 68 & 64 & 4 & 0.94 & TRA & New Zealand & SUBANT & $2006-2007$ & Thompson (2010a) \\
\hline ARGRI & 72 & 65 & 7 & 0.90 & $<0.0001$ & 73 & 73 & 0 & 0.92 & TRA & New Zealand & SUBANT & $2006-2007$ & Thompson (2010a) \\
\hline ARGRI & 26 & 22 & 4 & 0.85 & $<0.001$ & 26 & 24 & 2 & 0.92 & TRA & New Zealand & SUBTRS, SUBANT & 1998 & Robertson (2000) \\
\hline ARGRI & 92 & 87 & 5 & 0.95 & $<0.0001$ & 94 & 94 & 0 & 1.00 & TRA & New Zealand & SUBTRS, SUBANT & 2008-2009 & Thompson (2010b) \\
\hline ARGRI & 227 & 196 & 31 & 0.86 & $<0.0001$ & 226 & 196 & 30 & 0.87 & TRA & New Zealand & SUBTRS, SUBANT & $2000-2001$ & Robertson et al. (2003) \\
\hline ARGRI & 98 & 85 & 13 & 0.87 & $<0.0001$ & 99 & 97 & 2 & 0.98 & PLL, TRA & New Zealand & SUBTRS, SUBANT & $2001-2002$ & Robertson et al. (2004) \\
\hline PUGRI & 166 & 153 & 13 & 0.92 & $<0.0001$ & 166 & 166 & 0 & 1.00 & TRA & New Zealand & SUBANT & $2005-2006$ & Thompson et al. (2009) \\
\hline PRAEQ & 36 & 25 & 11 & 0.69 & $<0.05$ & 36 & 30 & 0 & 0.83 & PLL, TRA & New Zeland & SUBANT & $2006-2007$ & Thompson (2010a) \\
\hline PRAEQ & 14 & 10 & 4 & 0.71 & ns & 14 & 14 & 0 & 1.00 & DLL, TRA & New Zealand & SUBANT & 1998-1999 & Robertson and Bell (2002) \\
\hline PRAEQ & 33 & 21 & 12 & 0.64 & ns & na & na & na & na & DLL & South Africa & SUBTRS & 1994 & Barnes et al. (1997) \\
\hline PRAEQ & 379 & 300 & 79 & 0.79 & $<0.0001$ & na & na & na & na & DLL & Kerguelen & SUBANT & $2001-2003$ & Delord et al. (2005) \\
\hline PRAEQ & 12 & 6 & 6 & 0.50 & ns & na & na & na & na & DLL & Argentina & SUBANT & $2000-2001$ & Gandini and Frere (2006) \\
\hline PRAEQ & 5189 & 3767 & 1422 & 0.73 & $<0.0001$ & na & na & na & na & DLL & Kerguelen & SUBANT & $2003-2006$ & Delord et al. (2010) \\
\hline PRAEQ & 790 & 664 & 126 & 0.84 & $<0.0001$ & 85 & 75 & 10 & 0.88 & DLL & Prince Edward & SUBANT & $1996-2000$ & Nel et al. (2002a) \\
\hline PRAEQ & 233 & 194 & 39 & 0.83 & $<0.0001$ & 233 & 232 & 1 & 1.00 & DLL & Prince Edward & SUBANT & 1996-1997 & $\begin{array}{l}\text { Ryan and Box-Hinzen } \\
\text { (1999) }\end{array}$ \\
\hline PRAEQ & 56 & 28 & 28 & 0.50 & ns & na & na & na & na & DLL & Argentina & SUBANT & 2005 & Seco-Pon et al. (2007) \\
\hline PRAEQ & 694 & 410 & 284 & 0.59 & ns & 823 & 337 & 486 & 0.41 & PLL & South Africa & SUBTRS & 1998-2005 & Petersen et al. (2010) \\
\hline
\end{tabular}




\begin{tabular}{|c|c|c|c|c|c|c|c|c|c|c|c|c|c|c|}
\hline PRAEQ & 45 & 22 & 23 & 0.48 & ns & 45 & 45 & 0 & 1.00 & PLL & Australia & SUBANT & 1988-1995 & Gales at al. (1998) \\
\hline PRAEQ & 33 & 13 & 20 & 0.39 & ns & na & na & na & na & PLL & Brazil & SUBTRS & $2006-2008$ & Roma (2009) \\
\hline PRAEQ & 75 & 64 & 11 & 0.85 & $<0.0001$ & 75 & 75 & 0 & 1.00 & TRA & New Zealand & SUBTRS, SUBANT & 2008-2009 & Thompson (2010b) \\
\hline PRAEQ & 274 & 198 & 76 & 0.72 & $<0.0001$ & 278 & 275 & 3 & 0.99 & PLL, TRA & New Zealand & SUBTRS, SUBANT & $2000-2001$ & Robertson et al. (2003) \\
\hline PRAEQ & 356 & 284 & 72 & 0.80 & $<0.0001$ & 360 & 358 & 2 & 0.99 & DLL & New Zealand & SUBTRS, SUBANT & 2001-2002 & Robertson et al. (2004) \\
\hline PRAEQ & 52 & 37 & 15 & 0.71 & $<0.005$ & 55 & 55 & 0 & 1.00 & PLL, TRA & New Zealand & SUBANT & 2005-2006 & Thompson et al. (2009) \\
\hline PRCIN & 16 & 1 & 15 & 0.06 & $<0.0001$ & 16 & 15 & 1 & 0.94 & PLL & New Zeland & SUBTRS & 1989 & Bartle (1990) \\
\hline PRCIN & 45 & 2 & 43 & 0.04 & $<0.0001$ & 47 & 47 & 0 & 1.00 & PLL & New Zeland & SUBTRS & 1988-1992 & Murray et al. (1993) \\
\hline PRCIN & 16 & 14 & 2 & 0.88 & $<0.01$ & na & na & na & na & DLL & Prince Edward & SUBANT & $1996-2000$ & Nel et al. (2002a) \\
\hline PRCIN & 27 & 8 & 19 & 0.30 & 0.0500 & 27 & 27 & 0 & 1.00 & PLL & Australia & SUBANT & 1988-1995 & Gales at al. (1998) \\
\hline PRCIN & 27 & 2 & 23 & 0.07 & $<0.0001$ & 27 & 27 & 0 & 1.00 & PLL & New Zealand & SUBTRS & 2006-2007 & Thompson (2010a) \\
\hline PRCIN & 73 & 3 & 70 & 0.04 & $<0.0001$ & 73 & 73 & 0 & 1.00 & PLL & New Zealand & SUBTRS, SUBANT & 1998 & Robertson (2000) \\
\hline PRCIN & 46 & 37 & 9 & 0.80 & $<0.0001$ & 48 & 48 & 0 & 1.00 & DLL & New Zealand & SUBANT & 1998-1999 & Robertson and Bell (2002) \\
\hline PRCIN & 47 & 43 & 4 & 0.91 & $<0.0001$ & 179 & 179 & 0 & 1.00 & DLL & New Zealand & SUBTRS, SUBANT & $2000-2001$ & Robertson et al. (2003) \\
\hline PTGOU & 12 & 11 & 1 & 0.92 & $<0.01$ & 12 & 11 & 1 & 0.92 & DLL & New Zealand & SUBTRS, SUBANT & $2000-2002$ & Robertson et al. (2004) \\
\hline LAGLA & 103 & 50 & 53 & 0.49 & ns & 82 & 65 & 17 & 0.79 & DLL & Alaska & SUBARC & 2005 & Phillips et al. (2010) \\
\hline LAHYP & 21 & 10 & 11 & 0.48 & ns & 23 & 1 & 22 & 0.04 & DLL & Alaska & SUBARC & 2005 & Phillips et al. (2010) \\
\hline AYFUL & 15 & 11 & 4 & 0.73 & ns & 15 & 14 & 1 & 0.93 & GIL & Baltic Sea & SUBARC & $1972-76,1986-90$ & Stempniewicz (1994) \\
\hline CLHYE & 591 & 361 & 230 & 0.61 & $<0.0001$ & 591 & 410 & 181 & 0.69 & GIL & Baltic Sea & SUBARC & $1972-76,1986-90$ & Stempniewicz (1994) \\
\hline MEFUS & 284 & 180 & 104 & 0.63 & $<0.0001$ & 284 & 188 & 96 & 0.66 & GIL & Baltic Sea & SUBARC & $1972-76,1986-90$ & Stempniewicz (1994) \\
\hline AYAMA & 93 & 48 & 45 & 0.52 & ns & 93 & 53 & 40 & 0.57 & GIL & Baltic Sea & SUBARC & $1972-76,1986-90$ & Stempniewicz (1994) \\
\hline
\end{tabular}




\begin{tabular}{|c|c|c|c|c|c|c|c|c|c|c|c|c|c|c|}
\hline MENIG & 74 & 37 & 37 & 0.50 & ns & 74 & 18 & 56 & 0.24 & GIL & Baltic Sea & SUBARC & $1972-76,1986-90$ & Stempniewicz (1994) \\
\hline SOMOL & 68 & 38 & 30 & 0.56 & ns & 68 & 22 & 46 & 0.32 & GIL & Baltic Sea & SUBARC & $1972-76,1986-90$ & Stempniewicz (1994) \\
\hline POCRI & 24 & 11 & 23 & 0.46 & ns & 24 & 20 & 4 & 0.83 & GIL & Baltic Sea & SUBARC & $1972-76,1986-90$ & Stempniewicz (1994) \\
\hline MEANT & 42 & 26 & 16 & 0.62 & ns & 42 & 28 & 14 & 0.67 & GIL & New Zeland & SUBANT & 1979-1997 & Darby and Dawson (2000) \\
\hline SPMAG & 21 & 12 & 9 & 0.57 & ns & 21 & 21 & 0 & 1.00 & TRA & Argentina & SUBANT & 1995-1997 & Gandini et al. (1999) \\
\hline SPMAG & na & na & na & na & na & 20 & 16 & 4 & 0.80 & GIL & Brazil & SUBTRS & 2009 & Cardoso et al. (2011) \\
\hline SPMAG/SPHUM & na & na & na & na & na & 663 & 278 & 385 & 0.42 & GIL & Chile & SUBANT & 1991-1996 & Simeone et al. (1999) \\
\hline URAAL & 252 & 141 & 111 & 0.56 & ns & 252 & 159 & 93 & 0.63 & GIL & NE Pacific & SUBARC & 1994-1994 & Thompson et al. (1998) \\
\hline URAAL & 123 & 68 & 55 & 0.55 & ns & 123 & 34 & 89 & 0.28 & GIL & NE Pacific & SUBARC & 1995-2001 & Smith and Morgan (2005) \\
\hline URAAL & na & na & na & na & na & 765 & 237 & 528 & 0.31 & GIL & Baltic Sea & SUBARC & 1972-1999 & Osterblom et al. (2002) \\
\hline URAAL & 785 & 554 & 231 & 0.71 & $<0.0001$ & 785 & 411 & 374 & 0.52 & GIL & NE Pacific & SUBTRN & $1999-2000$ & Nevins et al. (2004) \\
\hline CEMON & 70 & 32 & 38 & 0.46 & ns & 70 & 15 & 55 & 0.21 & GIL & NE Pacific & SUBARC & 1994-1994 & Thompson et al. (1998) \\
\hline CEMON & 82 & 55 & 27 & 0.67 & $<0.01$ & 82 & 69 & 13 & 0.84 & GIL & NE Pacific & SUBARC & 1995-2001 & Smith and Morgan (2005) \\
\hline PHCAR & na & na & na & na & na & 289 & 27 & 262 & 0.09 & POU & North Sea & SUBARC & 1983-1992 & $\begin{array}{l}\text { Bregnballe and } \\
\text { Frederiksen (2006) }\end{array}$ \\
\hline PHPUN & 32 & 22 & 10 & 0.69 & 0.0518 & 33 & 21 & 12 & 0.64 & TRA & New Zealand & SUBTRS, & 2008-2009 & Thompson (2010b) \\
\hline
\end{tabular}

${ }^{1}$ Abbreviation for species is composed by the two first characters of the generic epithet and the three first of the specific epithet: DIEXU, Diomedea exulans; DIANT, Diomedea antipodensis; THMEL, Thalassarche melanophris; THIMP, Thalassarche impavida; THSTE, Thalassarche steadi; THCAU, Thalassarche cauta; THSAL, Thalassarche salvini, THCHR, Thalassarche chrysostoma, THBUL, Thalassarche bulleri, THCHL, Thalassarche chlororhynchos; THCAR, Thalassarche carteri; PHIM, Phoebastria immutabilis; PHNIG, Phoebastria nigripes; PHIRR, Phoebastria irrorata, MAGIG, Macronectes giganteus; MAHAL, Macronectes halli; FUGLA, Fulmarus glacialis; LAGLA, Larus glaucescens; LAHIP, Larus hiperboreus; PUCAR, Ardenna carneipes; PRAEQ, Procellaria aequinoctialis; ARTEN, Ardenna tenuirostris, ARGRI, Ardenna grisea; PRCIN, Procellaria cinerea; POCRI, Podiceps cristatus; PTGOU, Pterodroma gouldi; MEANT, Megadyptes antipodes; SPMAG, Spheniscus magellanicus; SPHUM, Spheniscus humboldti; URALG, Uria aalge; CEMON, Cerorhinca monocerata; AYFUL, Aythya fuligula; CLHYE, Clangula hyemalis; MEFUS, Melanitta fusca; AYMAR, Aythya marila; MENIG, Melanitta nigra; PHCAR, Phalacrocorax carbo; PHPUN, Phalacrocorax punctatus; SOMOL, Somateria mollissima. 